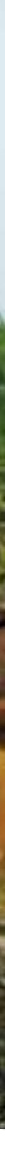

\title{
Policies and institutional and legal frameworks in the expansion of Brazilian biofuels
}

Renata Marson Teixeira de Andrade

Andrew Miccolis 



\section{Policies and institutional and legal frameworks in the expansion of Brazilian biofuels}

Renata Marson Teixeira de Andrade Universidade Católica de Brasilia

Andrew Miccolis

Instituto Salvia 
Working Paper 71

(C) 2011 Center for International Forestry Research

All rights reserved

de Andrade, R.M.T. and Miccolis, A. 2011 Policies and institutional and legal frameworks in the expansion of Brazilian biofuels. Working Paper 71. CIFOR, Bogor, Indonesia

\section{Cover photo $\odot$ Renata Marson Teixeira de Andrade}

This paper has been produced with the financial assistance of the European Union, under a project titled, 'Bioenergy, sustainability and trade-offs: Can we avoid deforestation while promoting bioenergy?' The objective of the project is to contribute to sustainable bioenergy development that benefits local people in developing countries, minimises negative impacts on local environments and rural livelihoods, and contributes to global climate change mitigation. The project will achieve this by producing and communicating policy relevant analyses that can inform government, corporate and civil society decision-making related to bioenergy development and its effects on forests and livelihoods. The project is managed by CIFOR and implemented in collaboration with the Council on Scientific and Industrial Research (South Africa), Joanneum Research (Austria), the Universidad Nacional Autónoma de México and the Stockholm Environment Institute. The views expressed herein can in no way be taken to reflect the official opinion of the European Union.

\section{CIFOR}

Jl. CIFOR, Situ Gede

Bogor Barat 16115

Indonesia

$\mathrm{T}+62(251) 8622-622$

F $+62(251) 8622-100$

E cifor@cgiar.org

\section{www.cifor.org}

Any views expressed in this publication are those of the authors. They do not necessarily represent the views of CIFOR, the authors' institutions or the financial sponsors of this publication. 


\section{Table of contents}

Abbreviations $\quad \mathbf{v}$

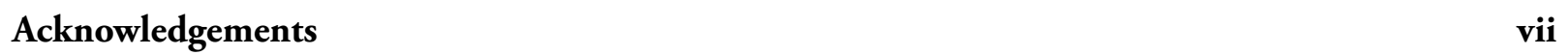

1 Introduction 1

2 Biofuels development in Brazil $\quad 2$

2.1 History of sugarcane ethanol: 1904-2011 2

2.2 History of biodiesel in Brazil $\quad 5$

3 Biofuels policy $\quad 8$

$\begin{array}{ll}3.1 & \text { Energy policy }\end{array}$

$\begin{array}{ll}3.2 \text { Ethanol policy } & 10\end{array}$

$\begin{array}{ll}3.3 \text { Agroenergy policy } & 10\end{array}$

$\begin{array}{ll}3.4 \text { Biodiesel policy } & 11\end{array}$

4 Institutional and legal framework relevant to biofuels development 12

4.1 The National Production Program: Law No. 11.097/05 12

4.2 The Brazilian environmental and legal framework relevant to biofuels 14

4.3 Foreign Direct Investment - FDI legal framework 20

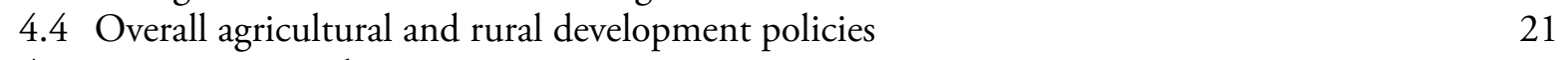

\begin{tabular}{ll}
4.5 & Access to natural resources \\
\hline
\end{tabular}

\begin{tabular}{ll}
4.6 & Land tenure \\
\hline
\end{tabular}

4.7 Land acquisition and availability 22

4.8 Structural constraints for smallholders and traditional communities 24

4.9 Policies targeting family farmers and traditional communities 25

4.10 Socio-biodiversity production chains 26

$\begin{array}{ll}4.11 \text { Zoning instruments } & 26\end{array}$

5 Implementation and performance $\quad 27$

5.1 Labour and human rights issues in the sugarcane-ethanol industry 27

5.2 Analysis of respective interests in the sector, power differentials and avenues of influence 27

$\begin{array}{ll}5.3 \text { Effectiveness of environmental regulations } & 29\end{array}$

5.4 Land concentration in the hands of large ethanol corporations and displacement of smallholders

5.5 Effectiveness of energy and agroenergy policies 31

5.6 Effectiveness of trade and investment policy 32

5.7 Biodiesel subject to oil market $\quad 32$

5.8 Effectiveness of the PNPB and Social Fuel Stamp 32

6 Conclusions $\quad 34$

$\begin{array}{ll}\text { References } & 36\end{array}$ 


\section{List of figures, tables and boxes}

\section{Figures}

1 Brazil and biofuels potential according to the Biodiesel Atlas 7

2 Potential ethanol expansion in Brazil in $2010 \quad 17$

3 São Paulo State ZAE for sugar ethanol expansion 18

4 The agricultural sectors with the highest numbers of accidents in Brazil, 1999-2008 28

\section{Tables}

1 Environmental regulation legal framework 14

2 National ZAE for sugarcane in Brazil (MAPA 2008) 16

3 Taxes in Brazil 21

4 Production, planted area and productivity of sugarcane (EPE 2009) 23

5 Increase of cropland area needed to achieve 5\% blend of biodiesel by $2009 \quad 24$

\section{Boxes}

1 Arco Verde Terra Legal Program [Green Arc Legal Land Program] 22

2 National Technical Assistance and Rural Extension Policy (ATER) 26

3 National efforts to tackle forced labour 28 


\section{Abbreviations}

\begin{tabular}{|c|c|}
\hline AGU & Attorney General’s Office (Advocacia Geral da União) \\
\hline ANP & National Agency of Petroleum, Natural Gas and Biofuels \\
\hline APEX & Agency for Promoting Exports \\
\hline BNDES & $\begin{array}{l}\text { Brazilian National Development Bank (Banco Nacional de Desenvolvimento Econômico } \\
\text { e Social) }\end{array}$ \\
\hline CAMEX & Foreign Trade Chamber \\
\hline CEIB & Comissão Executiva Interministerial \\
\hline Ceplac & Cocoa Development Agency (Comissão Executiva do Plano da Lavoura Cacaueira) \\
\hline CIMA & Comissão Interna de Meio Ambiente \\
\hline CNPE & National Energy Policy Council \\
\hline COFINS & Social Security Tax, or Social Integration Tax \\
\hline CONAB & National Supply Agency \\
\hline CONAMA & National Environmental Council \\
\hline EMBRAPA & $\begin{array}{l}\text { National Agricultural and Livestock Research Organisation (Empresa Brasileira de Pesquisa } \\
\text { Agropecuária) }\end{array}$ \\
\hline EIA & Environmental impact assessment \\
\hline EMATER & Technical Assistance and Rural Extension Agency \\
\hline EPE & Energy Research Company \\
\hline FAESP & São Paulo State Agriculture Federation \\
\hline FAO & Food and Agriculture Organisation \\
\hline FDI & Foreign Direct Investment \\
\hline IAA & Sugar and Alcohol Institute (Instituto do Açúcar e do Álcool) \\
\hline IBAMA & Brazilian Institute for the Environment and Renewable Natural Resources \\
\hline IBGE & National Statistics and Geography Bureau \\
\hline ICMS & State valued-added tax \\
\hline INCRA & National Colonization and Agrarian Reform Institute \\
\hline INSS & Social Security Agency, Social Security Tax \\
\hline IPI & Tax on Industrialised Products \\
\hline IPEA & Applied Economic Research Institute \\
\hline IRPF & Personal income tax \\
\hline IRPJ & Corporate income tax \\
\hline ISPN & Instituto Sociedade População e Natureza \\
\hline MAPA & Ministry of Agriculture, Livestock and Food Supply \\
\hline MDA & Ministry for Agrarian Development \\
\hline MDIC & Ministry of Development, Industry and Trade \\
\hline MF & Ministry of Finance \\
\hline MMA & Ministry of the Environment \\
\hline
\end{tabular}




$\begin{array}{ll}\text { MME } & \text { Ministry of Mines and Energy } \\ \text { MP } & \text { Office of Public Prosecution (Ministério Público) } \\ \text { MPS } & \text { Ministry of Social Security } \\ \text { MTE } & \text { Ministry of Labour } \\ \text { ORPLANA } & \text { Organisation of Sugarcane Planters } \\ \text { PAA } & \text { National Food Procurement Program (Programa de Aquisição de Alimentos) } \\ \text { PAC } & \text { Program for Accelerated Growth } \\ \text { PASEP } & \text { Civil Servant Asset Formation Program, a social security tax for civil servants } \\ \text { PNA } & \text { National Agroenergy Plan } \\ \text { PNPB } & \text { National Biodiesel Production Program } \\ \text { PNPCT } & \text { National Policy for the Sustainable Development of Traditional Peoples and Communities } \\ \text { PPA } & \text { Permanent Preservation Area } \\ \text { PTLA } & \text { Green Arc Legal Land Program } \\ \text { RBTB } & \text { Brazilian Network of Biodiesel Technology } \\ \text { RDS } & \text { Sustainable Development Reserves } \\ \text { RESEX } & \text { Extractivist Reserves } \\ \text { RSPO } & \text { Roundtable on Sustainable Palm Oil } \\ \text { SAF } & \text { Secretariat of Family Farming } \\ \text { Sebrae } & \text { Brazilian Service of Support for Micro and Small Enterprises } \\ \text { SMA } & \text { Sáo Paulo State Environment Secretariat } \\ \text { SNUC } & \text { National System of Conservation Units } \\ \text { UBRABIO } & \text { Brazilian Union of the Biodiesel Industry } \\ \text { UNICA } & \text { National Union of Sugarcane and Ethanol Industry } \\ \text { ZAE } & \text { Agro-ecological Zoning } \\ & \end{array}$




\section{Acknowledgements}

This paper is the result of ongoing research conducted by the authors since 2009 with the support of the following institutions. We would like to thank the Energy and Biosciences Institute at the University of California for the sub-award which has provided essential funding and ongoing support for various components of our research throughout the last two years. We also greatly appreciate the support from anonymous reviewers for their valuable comments, and CIFOR and the World Agroforestry Centre and the invitation extended by Fabiano Toni, Roberto Porro, Omar Masera, Pablo Pacheco and George Schoneveld to publish our work on biodiesel in the Amazon as well as the present paper on biofuels policies and players in Brazil. Lastly, we thank researchers at the Biofuels Governance Research Group - NUGOBIO/Universidade Católica de Brasília for their insightful comments and cutting-edge research. 



\section{Introduction}

Brazil is home to one of the world's oldest and boldest biofuels programs. Over the past 35 years, the Brazilian Government has invested heavily in expanding agribusiness and promoting the biofuels industry, thrusting the country into the international spotlight as a top producer, exporter and consumer of this 'green' fuel and several other commodities. Developments in the Brazilian ethanol and biodiesel landscapes are being closely watched in consumer markets such as the US and the EU. They are also being replicated by other countries, especially in Latin America and Africa, where Brazil is exporting technological and policy knowhow through topnotch public institutions such as Empresa Brasileira de Pesquisa Agropecuária (Embrapa, or National Agricultural and Livestock Research Organisation) and industry groups. So the lessons learned from the Brazilian example are bound to have lasting effects on the policies and guidelines for spreading biofuels production throughout the developing world. However, different feedstocks in Brazil have followed different trajectories, each driven by a distinct set of forces, policies and discourses.

This paper maps out the key Brazilian policies and programmes within and outside the biofuels sectors which affect the expansion and development of bioenergy projects nationwide. Sections 1 and 2 analyse the historical factors contributing to the early development and rapid expansion of biofuels in Brazil, focusing on ethanol and biodiesel.

Sections 3 and 4 lay out the institutional and political frameworks directly and indirectly influencing the biofuels sector, such as the national
Energy Policy, Ethanol Policy, Agroenergy Policy and Biodiesel Policy. Relevant environmental policies and extra-sectoral regulations include the Forest Code, National Environmental Policy, agricultural and rural development policies, and zoning mechanisms, as well as Foreign Direct Investment (FDI), taxes and land acquisition policies.

Section 5 analyses biofuels policy formulation and governance structures by shedding light on the complexities in the relationship between the State, industry and civil society. We draw from three examples to illustrate how social movements and industry interests influence ethanol policies, especially as environmental and labour laws regulate production and apply sanctions such as the National Program for Promoting Decent Work in the sugarcane industry, the Law Phasing Out Sugarcane Burning in 2002, the Agro-Environmental Protocol and the National Biodiesel Production Program (PNPB).

To assess the outcomes of these policies, Section 5 focuses on case studies showing intended and unintended consequences. For example, on the one hand, the policies have facilitated the establishment of the world's largest sugarcane-ethanol industry; increased foreign and national, private and public investment and $\mathrm{R} \& \mathrm{D}$; and, increased mechanisation and productivity. On the other hand, some stakeholders claim that certain feedstocks have led to the deforestation of sensitive ecosystems, undermined rural livelihoods, concentrated land in the hands of large corporations, displaced smallholders and created a host of labour-related and human rights issues. 


\section{Biofuels development in Brazil}

Our initial analysis led us to divide biofuels policies in Brazil into two distinct categories for the purposes of this article: first, the sugarcane-ethanol industry and, second, biodiesel made from soybeans, beef tallow, oil palm and other oilseeds. While the history, discourse, policies and impacts of ethanol production have been closely intertwined with commercial sugar production on large landholdings, biodiesel has been touted by the Brazilian Government as strategic to promoting social inclusion and environmental sustainability among smallholders. ${ }^{1}$

This section is divided into two parts. The first presents the factors leading to the ethanol industry's development during three very distinct periods: 1900s-1970s, 1970s-2000 and from 2000 onwards. The second part highlights the evolution of the biodiesel industry, which emerged much more recently in Brazil through an altogether different set of policies, guidelines and incentives.

\subsection{History of sugarcane ethanol: 1904-2011}

The history of the sugarcane-ethanol industry in Brazil dates back hundreds of years to the days of slavery. Since then it has undergone varying degrees of State intervention in the sugar-ethanol market, logistics, labour laws and environmental regulations. Currently, according to the National Agriculture Confederation (Jornal da Cana 2006), even though $70 \%$ of sugarcane producers are considered smallscale farmers - which does not necessarily mean that they are 'family farmers' - roughly $80 \%$ of Brazilian ethanol production is concentrated in the hands of industrial-scale producers. These producers include remnants of regional oligarchies and international

1 This report is based largely on the findings of research funded by EBI/UC Berkeley with regard to the expansion of biofuels in Brazil, which has so far focused on: controversies surrounding human rights and environmental justice in the sugarcane-ethanol industry (Andrade and Miccolis 2010a); social and environmental issues regarding biodiesel policies, players, and social-environmental impacts, especially in the Amazon (Andrade and Miccolis 2010b). companies supplying ethanol to Shell, ESSO and Petrobrás, the State-owned oil giant.

These industrial-scale players are operating in a booming ethanol market growing in lockstep with the phenomenal rise of flex-fuel cars, which were launched in 2003 but already account for more than $90 \%$ of all new cars in Brazil. While touted by the Government as a mainstay of its climate change mitigation and energy independence strategies, ethanol's colossal rise has also had undesired effects, such as changes in land concentration, indirect land use changes and displacement of smallholders, territorial disputes between expanding sugarcane plantations and agrarian reform settlements (Fernandes et al. 2010), as well as associated labour violations and public health concerns stemming from pollution. While sugarcane production has been officially ruled out of expansion in the Amazon region and Pantanal wetlands under the Agroecological Zoning, it has raised eyebrows among human rights and environmental justice groups as it spreads rapidly across vast expanses of Cerrado (the central savannas of Brazil), South-Central Brazil, and parts of the Northeast (ISPN 2008; Abramovay 2008; Andrade 2006).

1900s-1970s. In 1903, the First National Congress on Industrial Applications of Alcohol proposed an industrial park to increase ethanol production for fuel purposes. In 1931, the Brazilian Government implemented a voluntary blend of at least 5\% anhydrous bioethanol into gasoline (Decree 19.717, signed by President Getúlio Vargas). The aim was to reduce the impacts of Brazil's dependency on petroleum-derived fuels while also taking advantage of surplus production in the sugar industry.

Initially, the mandate applied only to imported gasoline, but was later extended to domestically produced gasoline as well. The role of establishing prices, production quotas per mill and fuel blends was assigned to the Instituto do Açúcar e do Álcool (IAA, or Sugar and Alcohol Institute). In 1941, during World War II, the addition of ethanol to 
gasoline became mandatory. In 1942, Decree 4722 cast the ethanol industry as strategic for the Brazilian economy and of national interest, thenceforth establishing guaranteed prices for bioethanol and sugar. During this period, the main investments in sugarcane-ethanol were concentrated in the southeastern states, as maritime transport of sugar and ethanol from the northeast to the southeast was threatened by the war. After the war, sugarcane and ethanol production continued spreading in the southeast, especially in the fertile valleys of the State of São Paulo. In 1946, Decree 9827 regulated the industry's expansion nationwide and established production quotas for each region based on regional sugar consumption, so ethanol production was intrinsically linked to sugarcane production. Even though Decree 25174 in 1948 stimulated the production of dehydrated ethanol for fuel, ethanol regulation was encompassed by wider sugarcaneoriented policies until 1975.

1970s-2000. During the major oil crisis of the 1970s, the Federal Government created mechanisms to expand ethanol production (Decree 76593 of 1975 ) by blending ethanol into gasoline at $20-25 \%$ (E-20), which in and of itself created a huge domestic ethanol market. Furthermore, after attaching distillers to sugar mills, developing ethanol-fueled engines for passenger vehicles, and encouraging ethanol-chemical industries, the Government managed to quadruple ethanol production through the federallyfunded programme known as ProAlcool (Pro-Alcohol). These policies also protected sugarcane farmers as international sugar prices also dropped during this period. For the sugarcane farmers, it was more advantageous to shift from sugar to ethanol production and avoid bankruptcy after intense investments in modernising the sugarethanol distilleries and mills during the 1950s and 1960s. Despite these incentives, however, there was still a pressing need for measures to regulate ethanol stocks and distribution as well as define roles and responsibilities in regulating this market. In 1983, Petrobrás took over the role of stocking and purchasing ethanol to be sold at the pump (Decree 88626/83).

Overall production of dehydrated ethanol in Brazil increased steadily from 150 million litres in 1923 to 650 million litres in 1941, reaching 12.6 billion litres in 1995. According to Moreira and Goldemberg (1999), the increased production and use of ethanol as a fuel from 1979 to 1985 was enabled by three government measures: 1) the decision that Petrobrás would purchase a guaranteed amount of ethanol; 2) economic incentives for ethanol producers, offering low interest rates from 1980 to 1985, which accounted for $30 \%$ of the total investment used to achieve the 1999 installed capacity using a system of attached distilleries; and, 3) the Government policy aimed at bolstering the consumer market by selling ethanol at the pump $40-80 \%$ cheaper than gasoline. This was only possible because the Government set gasoline prices at about double US prices.

From 1985 until 1990, concerns over ethanol shortages mounted because of rising international sugar prices, leading the Government to increase ethanol stocks in 1987 (Decree 94541). The volatility of the sugar market ultimately left ethanol-fueled cars without fuel, which led car manufacturers to stop producing them. Furthermore, oil prices were stable at that point and Petrobrás had discovered new offshore oil reserves.

Thus, the Pro-Alcool Program ended due to inadequate planning, since it did not manage to strike a balance between supply and demand. Withdrawing the direct subsidies dealt a serious blow to the industry. Ethanol was no longer as attractive as gasoline at the pump, and excessive costs related to ethanol distribution had created a deficit for Petrobrás. Even more importantly, concerns over stock logistics remain to this day, as the ethanol sector has been highly deregulated since the end of Pro-Alcool, as discussed in the section below.

The 2000s. After the 1988 Constitution, the ethanol sector underwent sweeping deregulation. Up until the beginning of the 1990s, many gasoline-fueled car owners filled up their tanks with ethanol because it was cheaper than gasoline, but users were not inclined to buy ethanol-run cars for lack of trust in the ethanol market. Then, the Federal Government created the National Agency of Petroleum, Natural Gas and Biofuels (ANP) in 2000. The ANP drafted guidelines for ethanol price regulation and regional price equalisation that were meant to offset the higher logistical costs of producing sugarcane in Brazil's northeast. In 2002, 
the National Union of Sugarcane and Ethanol Industry (UNICA) conducted a consumer survey, confirming that the ethanol market needed to be consolidated with a flex-fuel car programme. A year later, the first flex-fuel cars were sold, marking the beginning of a revolution in the car industry propelling the expansion of the sugarcane-ethanol industry in Brazil ever since (Smeets et al. 2006, Walter et al. 2008).

As a result, Brazil is currently the world's second largest ethanol producer, behind the US. It reached a record 17.4 billion litres in 2006/07 and 27 billion litres in 2008/09, 19\% above 2007 production. The so-called Central-Southern region of Brazil produces approximately $90 \%$ of Brazilian ethanol (24.5 billion litres) and the North/Northeast produces the remaining $10 \%$ ( 2.5 billion litres). In 2008 , roughly 4.2 billion litres of ethanol were intended for export and an estimated 35 billion litres/year will be produced by 2012 (MAPA 2006).

During the two terms of President Lula's administration (2003-2010), concerns over oil price increases and the need to reduce greenhouse gas emissions led to two key national plans. The National Agro-energy Plan (2005) and the National Climate Change Plan (2009) both called for biofuels expansion in Brazil. The National Agroenergy Plan was drafted in 2005 because 'there is an opportunity to incorporate new areas for agro-energy without competing with agriculture for food and with environmental and social impacts limited to acceptable levels. Thus, the area of expansion in the Cerrados, integrating livestockfarming activities, the degraded pastures, the areas of reforestation and the currently marginalised - as the Semi-Arid Northeast - total some 200 million hectares' (MAPA 2006).

Since 2005, large foreign-owned companies, including Bunge, Noble Group, Archer Daniels Midland) and Dreyfus, as well as megaentrepreneurs like George Soros and Bill Gates, have been purchasing ethanol and sugar plants in Brazil. The ethanol business has become so lucrative that in 2007, the largest ethanol producer in Brazil, the Cosan group, bought up Esso's distribution and retail operations in Brazil for US\$1 billion. In 2009, Shell and Cosan formed a joint venture worth
US $\$ 42$ billion, and ethanol blended gasoline from São Paulo State is entering the Dutch market.

From 2007 to 2008, the total area of sugarcane cultivation in Brazil increased by $11.43 \%$, from 7 million ha to 7.8 million ha. This trend is likely to continue so as to meet the rising demand for ethanol in domestic and foreign markets. Historically, for more than 300 years, the States of Alagoas and Pernambuco were the largest sugarcane producers, until the 1950s when the State of Sáo Paulo surpassed them in total sugarcane and ethanol production. Since 2003, the ethanol industry has expanded rapidly from the Northeast and São Paulo to the States of Rio de Janeiro, Minas Gerais, Espirito Santo, Paraná, Mato Grosso do Sul, Mato Grosso, Goiás, Tocantins, Pará and Amazonas. During the 2006/07 and the 2007/08 harvests, sugarcane cultivation increased in all regions, growing $24.1 \%$ in the South, $12.5 \%$ in the Southeast, $17.5 \%$ in Center-West, $7.4 \%$ in the Northeast and $8.5 \%$ in the North, where the Amazon forest is located (INPECANASAT 2009).

As the sugarcane-ethanol industry has been spreading its tentacles across the country, controversies linked to direct and indirect land use change and associated greenhouse gas emissions have raised eyebrows internationally and consequently within the Federal Government. In 2007 the Government commissioned an agroecological zoning of sugarcane to keep it from encroaching on the Amazon forest region. Spearheaded by the Ministry of Agriculture, Livestock and Food Supply through Embrapa and the Ministry of the Environment, with support from several other federal agencies and universities, this zoning rules out the Amazon and Pantanal regions for sugarcane plantations. It does this by barring farm loans for sugarcane and effectively banning new distillers from setting up shop by denying them environmental permits in these regions (Andrade and Miccolis 2010a).

Environmental regulation also plays an important role in shaping how the ethanol industry is expanding currently through easier environmental licensing, increasing FDI, changes in land tenure policies, and increased mechanisation, as determined by the Sugarcane Burning Phasing-out 
State Law (São Paulo State 2002, Brannstrom et al. 2011). As discussed by Andrade and Miccolis (2010a), among others, the São Paulo sugarcaneethanol industry is increasingly complying with environmental and labour laws and safety regulations. 'A growing number of initiatives such as the Agro-Environmental Protocol, Environmental Compliance Certificate and the National Commitment to Eradicate Slave Labour have been pointing to best practices as a means to reconciling the need for a clean and renewable source of energy with fair trade and sustainable environmental practices' (Andrade and Miccolis 2010a).

Hence, 30 years after undergoing intense regulation and being propped up by subsidies under the ProAlcool Program, and then initially collapsing once subsidies were removed in the 1990s, ethanol is on the verge of being regulated once again. The Brazilian Government has recently opened the door for direct price regulation, going well beyond the current mechanisms designed to keep ethanol competitive at the pump. A combination of market forces and climate factors led to this decision, which also reduced the mandatory blend of anhydrous ethanol into gasoline from $25 \%$ to $18 \%$. First, in 2010/11, the sale of dual fuel cars reached record levels, leading to a peak in demand for both anhydrous and hydrated ethanol at the pump. Meanwhile, the high price of sugar on the international market due to climate and market factors led distillers to target their production more towards sugar, thus reducing the supply of ethanol nationally. As a result, in 2011, Brazil was obliged to import anhydrous ethanol made from US corn to blend into gasoline, while hydrated ethanol prices rose sharply, prompting most car owners to shy away from ethanol altogether. In order to avert the risk of ethanol shortages and public outrage over soaring fuel prices, the Government has taken steps to reregulate ethanol through ANP and Petrobrás since April 2011, while also investing heavily in bolstering the industry's capacity for stockpiling ethanol so as to minimise such price fluctuations.

After laying out the history of ethanol and the key discourses and players driving its expansion, in Section 2.2 we discuss efforts aimed at rendering biodiesel production more sustainable in terms of social inclusion and markets.

\subsection{History of biodiesel in Brazil}

The second part of this section focuses on biodiesel policies, as the biodiesel industry has been growing thanks to a very strong national programme and regulations that set up social and tax incentives and $\mathrm{R} \& \mathrm{D}$ initiatives.

As discussed by Andrade and Miccolis (2010b), four main factors have led to a growing biodiesel industry in Brazil, namely: 1) the growing demand for biodiesel on domestic and international markets, which in Brazil is underpinned by a mandatory 5\% (B5) blend of biodiesel into diesel; 2) rising public and private investments in biodiesel R\&D and refining capacity for an increasing variety of feedstocks, especially soybeans (roughly 85\%) and beef tallow, both being top Brazilian exports, as well as cottonseed, sunflower, castor beans, African oil palm and native palm trees; 3) specific policies aimed at promoting biodiesel production among smallholders, such as the PNPB, which established tax benefits for refineries that source the feedstock from familybased farmers; and, 4) climate change policies and mechanisms aimed at reducing $\mathrm{CO}_{2}$ emissions targets, which tout bioenergy as 'green fuel' and work handinhand with energy policies.

The historical trajectory of biodiesel as a potential substitute for petroleum-based diesel began during the 1970s oil crisis, when the Brazilian Government set up two research programmes: the PROÓLEO (Plan for Producing Vegetable Oils for Energy Purposes), which enabled blending in natura rawvegetable oils into diesel so as to increase their production at competitive prices; and PRODIESEL and the Vegetable Oils Program - OVEG, which aimed to test different proportions of biodiesel in motor vehicles (Santos 2008).

Biodiesel is produced from vegetable oils or animal fats. Dozens of plant species in Brazil have been researched and used for producing biodiesel, among which one might underscore soybeans (Glycine max), oil palm (Elaeis guineensis), sunflower (Helianthus annuus), babassu nut (Attalea speciosa), peanuts (Arachis hipogaea), castor beans (Ricinus communis), jatropha (Jatropha curcas) and Brazil nuts (Bertholletia excelsa), in addition to beef tallow and 
spent cooking oil. The development of this agrofuel in Brazil surged from 2005, when a host of R\&D plans and biodiesel production projects sprang up in several Brazilian States (Andrade and Miccolis $2010 \mathrm{~b}$ ). These $\mathrm{R} \& \mathrm{D}$ projects have been strategically orchestrated by the Federal Government since 2003, when Luiz Inácio Lula da Silva began his first term as President. At the very outset of his presidency, Mr Lula set up an Interministerial Working Group (GTI) to lay out the top priorities for developing biodiesel (COPPEAD 2007).

Envisioning promising prospects for the future of biodiesel in relation to energy and environmental issues, agribusiness and social inclusion, the GTI reached out to different sectors to promote regional and local biodiesel development policies (Andrade and Miccolis 2010b). The National Biodiesel Production Program (PNPB), approved in 2004, organised the chain of production, defined funding mechanisms, supported the technological base and set up the regulatory framework for this new fuel (Roussef 2004; BiodieselBr no date).

The regulatory framework was presented in the first half of 2005, when President Lula sanctioned the Biodiesel Law (Lei do Biodiesel). This law introduced biodiesel into the energy mix, created a specific permit for biodiesel producers and importers, and set up the biodiesel social certification process known as the Social Fuel Stamp (Selo de Combustível Social), among other policies such as providing fiscal incentives for biodiesel sales (Andrade and Miccolis 2010b). Indeed, although the PNPB was only launched in 2005, biodiesel production jumped from zero to 1.8 billion litres within a few years. This market grew from zero to a B5 biodiesel $\mathrm{mix}^{2}$ by drawing from a largely untapped production capacity. UBRABIO, the Brazilian Union of Biodiesel Industry,forecasted a simple scenario of stepping up biodiesel production

2 The B factor is an internationally recognised system for the amount of biodiesel in any fuel mix. For example, 100\% biodiesel is referred to as B100, while 5\% biodiesel: $95 \%$ petrodiesel is labelled B5. from B3 to B4 in 2009, based on an annual consumption of diesel of around 45 billion litres per year. Beltrão (2009) explains that 'each $1 \%$ of biodiesel blended into diesel amounts to 450 million litres/year, thus the demand for $\mathrm{B} 3$ is equivalent to 1.35 billion litres/year, or 338 million litres/quarter; whereas the demand for B4 amounts to roughly 1.8 billion litres/year, or 450 million litres per quarter. Petrobrás is bound to increase, then, the amount it buys from industries by 112 million litres/quarter'.

In 2008, the NGO Repórter Brasil published a report analysing the potential social and environmental impacts of expanding agrofuels in Brazil.

Additionally, Butler and Laurance (2009) point to 'biodiversity loss and deforestation of untouched forests - as opposed to planting on degraded lands as potential environmental impacts of expanding oil palm in the Amazon'.

Launched in 2010, the National Oil Palm Program clearly signals the Brazilian Government's emphasis on oil palm as the major feedstock for biofuels expansion in the Amazon (Andrade and Miccolis 2010b). In order to access funds through this programme, farmers must commit to only using degraded lands, a provision aimed at allaying fears that oil palm might have devastating effects on biodiversity and livelihoods in the Amazon, much along the lines of what happened in Indonesia and Malaysia.

As discussed by Andrade and Miccolis (2010b), among others, 'in addition to being a species of palm that is well adapted to the humid tropics, oil palm holds a high capacity for sequestering carbon and for producing organic matter, which should contribute towards offsetting the effects of greenhouse gas emissions while also reducing soil erosion and leaching' (see also NAE 2004; Santos 2008; Villela 2009). As enthusiasm for oil palm grows, so do the voices that wish to avoid repeating the mistakes made in Malaysia and Indonesia, such as deforestation, land concentration and displacement of traditional communities (Fitzherbert et al. 2008). 
Atlas do Biodiesel - Potencialidade brasileira para produção e consurno de combustivels vegetais Biodiesel Atlas - Brazil's potential for production and consumption of vegetable fuel

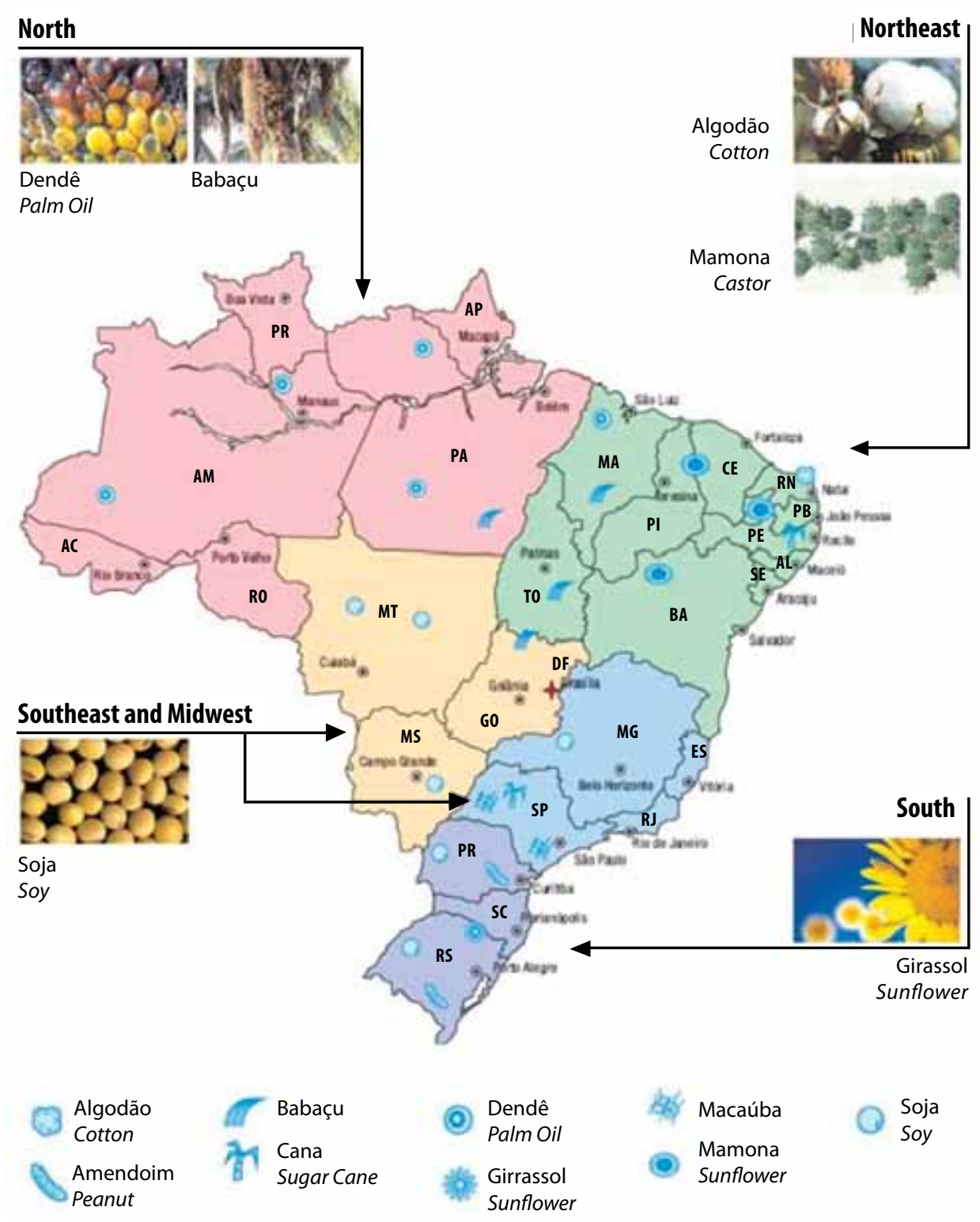

Figure 1. Brazil and biofuels potential according to the Biodiesel Atlas

Source: BiodieselBr (no date) 


\section{Biofuels policy}

Biofuels policy formulation is coordinated and drafted at the highest levels of the Brazilian Government: under the President's Office (CC/ PR), through an advisory body called the National Energy Policy Council (CNPE), and by two separate interministerial councils, CIMA (Interministerial Council for Sugar and Ethanol) and CEIB (Interministerial Executive Committee), dealing with sugarcane-ethanol and biodiesel, respectively. CIMA, the much smaller sugarcane-ethanol council, is led by the Agriculture Ministry and includes three other ministries: Development, Industry and Trade (MDIC), Mines and Energy (MME) and Finance (MF) (MAPA et al. 2006). Biodiesel policymaking, on the other hand, is formulated and implemented by CEIB, an unlikely assemblage of government agencies led by the President's Chief of Staff Ministry. It comprises a wide range of line ministries cutting across sectors, and coordinated through the interministerial National Biodiesel Production Program (PNPB). While regulated by the national petroleum, gas and biofuels agency (ANP) and coordinated by the Presidency and the Ministry of Mines and Energy, biodiesel policies and programmes are closely associated with agencies working on the other side of the spectrum, such as the Ministry for Agrarian Development (MDA), which coordinates policies aimed at smallholders and traditional communities, including land tenure and reform, family farming and technical assistance. So while ethanol's long trajectory has been interwoven with sugar and agricultural policies, agencies and farmers, the much more recent biodiesel policies drafted in 2005 and nestled in the heart of the executive branch, have been coordinated and regulated by energy sector agencies (MME and ANP) but implemented and supported largely through agencies tackling rural poverty and social exclusion.

The main arguments and policies supporting biofuels production in Brazil are grounded on notions of the country's aspirations to become a world leader in biofuels production, trade and technology, in addition to energy independence and territorial security, social and agrarian sustainability, and a solid environmental regulatory framework (Andrade and Miccolis 2010b).

The interests of the sugarcane-ethanol industry and lobby are equated with national welfare: i.e. 'what is good for sugarcane-ethanol is good for Brazil' (Brandt 2008). Among others, Brazilian President Lula da Silva and former Minister Chief of Staff to the President, Dilma Roussef (previously Minister of Mines and Energy and currently President) have publicly emphasised the important role to be played by the sugarcane-ethanol industry and its science and technology in making Brazil more competitive abroad.

Likewise, several government documents have championed the introduction of biodiesel into the Brazilian energy mix since it reduces diesel imports and greenhouse gases, thus increasing Brazil's energy sustainability and independence (Holanda 2004; MAPA 2006). According to the 2009 Annual Statistical Report of theNational Agency of Oil, Natural Gas and Biofuels (ANP), the use of biodiesel in 2008 replaced 1.1 billion litres of imported diesel, which meant annual savings of approximately US\$976 million. Furthermore, various studies have underscored the environmental advantages of using biodiesel, claiming it reduces greenhouse gas emissions by $78 \%$ and sulfur particles and compounds by $90 \%$ (Holanda 2004; Coelho 2008; MAPA 2006). The UBRABIO president, Sérgio Beltrão, aptly summed up the benefits of biodiesel: 'more partnerships and stronger ties between biodiesel producers and family farmers; spurring economic activity, fighting the effects of the crisis; job creation in rural areas, in industry and in related services; positive impacts on the trade balance due to reduced diesel imports and more favourable prices for Brazilian vegetable oil exports'. ${ }^{3}$

3 Interview with Sergio Beltrão in Brasília, 2 August 2009 conducted by Renata Marson Teixeira de Andrade. 


\subsection{Energy policy}

Energy security is one of the key arguments driving the expansion of ethanol and biodiesel production in Brazil, which favours domestic feedstock production to substitute fossil fuel derivatives. Preliminary data from Brazil's 2008 National Energy Balance (EPE 2009) indicates that for the first time in history, sugarcane ethanol accounted for 16\% of the Brazilian energy supply matrix in 2007, ahead of hydraulic energy and second only to oil and its derivatives. According to the chair of the Energy Research Company (EPE), Mauricio Tolmasquim, '(2008) is a historic year in that sense, and an irreversible trend' (Luna 2008).

This trend stems largely from energy policy in Brazil, especially Law 9478/97 which defined the principles and objectives of the National Energy Policy and Plan. According the National Energy Plan (20102019), the projected ethanol demand for 2019 will be 52.4 billion litres, based on the blend of ethanol into gasoline and car sales.

Additionally, the use of cellulosic subproducts of ethanol and biodiesel has been increasingly prominent in energy production thanks to Law 10438/2002, the National Program of Incentives for Alternative Electricity Sources (PROINFA, Programa de Incentivo a Fontes Alternativas de Energia Elétrica). PROINFA supports the use of sugarcane bagasse as a renewable energy source for electricity through cogeneration. The policy's first stage promoted renewable technologies (specifically wind, biomass [cogeneration] and small hydro) through incentives and subsidies. Once the first phase objectives were achieved, the second phase was aimed at increasing the share of renewables to $10 \%$ of annual energy consumption. Also in this phase, participating plants were required to issue Renewable Energy Certificates annually in proportion to the amount of clean energy they produced.

The first phase subsidies/incentives were funded through the Energy Development Account. Consumers pay into this account through higher energy bills (from which low-income sectors are exempt). To support this programme, the Banco
Nacional de Desenvolvimento Econômico e Social (BNDES, Brazilian National Development Bank) has special financing available for these renewable projects as well (up to $70 \%$ of capital costs, excluding site acquisition and imported goods and services) at the basic national interest rates plus $2 \%$ of basic spread and up to $1.5 \%$ of risk spread, although no interest is charged during construction. PROINFA introduced $3300 \mathrm{MW}$ of renewable energy by 2007 , including wind, biomass cogeneration, and microhydropower. By early 2005, the first phase was finished and $3300 \mathrm{MW}$ were completed (1266 MW micro-hydropower, $655 \mathrm{MW}$ Biomass, $1379 \mathrm{MW}$ Wind) (IEA 2010).

R\&D undoubtedly also played a pivotal role in expanding biofuels in the energy mix. Law 9991 outlines the compulsory nature of $\mathrm{R} \& \mathrm{D}$ investment in renewable energy sources - 'the $1 \%$ obligation'. This provision obliges concession holders for public power electricity distribution services to allocate annually at least $0.75 \%$ of their net operational revenues in $\mathrm{R} \& \mathrm{D}$ in the electricity sector, and at least $0.25 \%$ in end-use efficiency programmes. Companies generating electricity solely from wind-driven, solar or biomass facilities and small hydroelectric plants were exempt from this obligation until the end of 2005.

Furthermore, government advocates for expanding sugarcane-ethanol have consistently cited scientific evidence attesting to the sustainability of sugarcaneethanol in relation to environmental and energy benefits and job creation (MAPA 2006; Dolzan et al. 2006; Macedo 2007a and 2007b; BNDES, CGEE 2008; Walter et al. 2008). Backed by these studies, the Brazilian Government laid out policies through the Ministry of Agriculture, Ministry of Science and Technology, and Ministry of Mines and Energy aimed at increasing the role of bioenergy in the energy mix and developing national and international markets for 'clean fuels'. To this day, ethanol is a mainstay of climate change mitigation policies due to its potential for reducing greenhouse gas emissions when added to gasoline and sequestering carbon in sugarcane plantations (MAPA 2006; Macedo 2007b). 


\subsection{Ethanol policy}

As discussed in more detail in Section 2, specific ethanol policies were designed to promote the industry's development in Brazil. The National Alcohol Program (Pro-Alcool) - Decree No. $76.593 / 1974$ - was the main driver for the ethanol industry's phenomenal growth in the 1970s-1980s. Public sector subsidies and tax breaks helped get the programme started, farmers planted more sugarcane, investors built distilleries to convert the crop to ethanol and automakers designed cars to run on $100 \%$ ethanol. The Government financed a distribution network to get the fuel to gas stations and kept ethanol prices low to entice consumers. Today, the price difference between gasoline mixed with ethanol and hydrated ethanol is defined by the Government (minus 30\% for hydrated ethanol).

In the early 1990s, Federal Law 8723/93 instituted a compulsory blend of anhydrous ethanol into gasoline (E20 to E25), which means that the percentage of ethanol mixed with gasoline is set at 20-25\%. This policy requires close coordination among all sectors involved: the Ministry of Agriculture and sugarcane planters, the Ministry of Science and Technology and research centres, the Ministry of Development, Industry and Trade, the automobile industry and owners, the Ministry of Mines and Energy, Petrobrás, the fuel distributors, filling stations and automobile owners, as well as the ministries of Finance, Planning, and the Environment.

\subsection{Agroenergy policy}

National Agroenergy Plan and Program (20062011): in 2005/06, an interministerial team drafted the National Agroenergy Policy Guidelines, which laid the foundations for bioenergy policies in Brazil. As a key component of the wider Federal Government policy, the Ministry of Agriculture, Livestock and Food Supply drafted the Brazilian Agroenergy Plan 2006-2011, aimed at promoting the competitiveness of Brazilian agribusiness and supporting specific programmes in energy, social inclusion and regional development. Indeed, this vision of a promising future for biodiesel as a potential commodity was part and parcel of the Brazilian agroenergy policies drafted from 2003 onwards. According to the Agroenergy
Policy Guidelines, factors that underpin Brazil's longstanding tradition in biofuels production and use include:

1. huge production potential: availability of land for extending agroenergy activities, including areas with a high income generation potential (among smallholders), adequate climate, soil and water availability, abundance of labourers, and business groups with enough muscle to make the necessary investments;

2. current and past levels of biofuels demand: the share of biofuels in the Brazilian energy mix in 2006 was approximately 29\% (MAPA 2006), compared to $11 \%$ worldwide; and,

3. control of the production process, storage and distribution of various biofuels (like ethanol, electrical energy is obtained by burning agricultural residues and charcoal for steel mills).

To provide a secure biofuels industry, agricultural policies were introduced to guarantee future investments in agroenergy $\mathrm{R} \& \mathrm{D}$ and guidelines for the expansion of biofuels agribusiness. On the one hand, specific policy objectives highlight the need to provide isolated and traditional communities, individual farmers through cooperatives or associations, and agrarian reform settlements with the means to generate their own energy, especially in Brazil's remote regions. On the other hand, great emphasis is placed on expanding agribusiness and supporting the sugarcane-ethanol sector on suitable lands so as to increase ethanol exports. Spearheaded by the Ministry of Agriculture, Livestock and Food Supply (MAPA), this programme was designed to develop the agroenergy industry, including cultivated energy forests on suitable lands ${ }^{4}$, and implement the biodiesel production chain nationally.

In principle, according to these guidelines, biofuels expansion should not affect food production for domestic consumption, especially staple foods. On the contrary, the programme guides producers to use biodiesel coproducts such as soy and sunflower seed meal, and supplement the supply of foodstuffs aimed at human and animal consumption. The policy also includes a long-term research, development and innovation programme for agricultural, livestock

4 These energy forests were made up of Eucalyptus mainly, according to the environmental and agroclimatic zoning. 
and industrial technologies and technology transfer tailored to biofuel production chains. The underlying rationale is the aim of bolstering Brazilian leadership in international biofuels trade and increasing exports, while also generating tax revenues and promoting national development.

\subsection{Biodiesel policy}

Drafted by the National Energy Policy Council and published on 13 January 2005, Law No. 11097/05 introduced biodiesel into the Brazilian energy mix and widened the role of ANP, thenceforth called the National Agency of Petroleum, Natural Gas and Biofuels. Based on this law, ANP took on the role of regulating and overseeing activities related to biodiesel production, quality control, distribution and sales, as well as the diesel-biodiesel blend (BX).

In January 2008, the biodiesel policy instituted the mandatory blend of $2 \%$ biodiesel into petrol-diesel sold in Brazilian filling stations. In July the same year, this percentage rose to $3 \%$. In a short period, then, this policy made Brazil a leading biodiesel producer in the world as its production jumped to 1.17 billion litres in 2008 (MAPA 2009). One indicator of the programme's success, especially for rising production, was the earlier than expected leap from
$2 \%$ to $3 \%$ in 2008 and to the current $4 \%$ as of July 2009. The National Energy Policy Council (CNPE) took this measure based on the suggestions made by COPPEAD (2007) and on the current supply and demand within the national biodiesel production chain. Since 2008, 42 plants have been installed nationwide, with a total production capacity of 3.6 billion litres per year (ANP 2009).

Policies aimed at developing the biodiesel oilseed production market within the large scale agribusiness sector, much along the lines of what was done with sugarcane-based ethanol, have been orchestrated by the Secretariat for Production and Agronergy within the MAPA, and by the Agency for Promoting Exports (APEX), which recommended the following measures:

- encouraging the territorial expansion of crops providing raw materials for biodiesel refineries through an agricultural-climatic and ecologicaleconomic zoning for several oilseeds;

- attracting national and international companies and agribusiness investors; and

- fostering the creation of centres of excellence and cutting-edge research on biodiesel production chains. 


\section{Institutional and legal framework relevant to biofuels development}

Brazil has a series of unique FDI, land tenure, forestry, labour, social inclusion and environmental policies that play a pivotal role in decisions surrounding the operation of biofuels production chains. In many ways, this wider regulatory framework is just as important as specific biofuelsoriented policies in determining crop expansion strategies and investments. This section sheds light on some structural issues in Brazil, the main institutional and legal frameworks inside and outside the biofuels sector, and how they stand as constraints and/or opportunities for expanding bioenergy, from the standpoint of both national and international investors and smallholders. ${ }^{5}$

\subsection{The National Production Program: Law No. 11.097/05}

The central pillar of the biodiesel regulatory framework is the National Biodiesel Production Program- PNPB. The framework establishes guidelines pertaining to biodiesel production, certification and marketing (Andrade and Miccolis 2010b). The overarching strategies for government decisionmaking on agriculture and agroenergy since the 1990s have been based on two cornerstones: raising the competitiveness of corporate farming, and strengthening family farming.

By 2006, MAPA set up the Biodiesel Production Chain Sectoral Chamber, which has a seat on the Agribusiness Council. Among other measures, the chamber puts forth 'proposals aimed at improving agricultural and livestock activities, by expanding domestic and foreign markets, creating jobs, generating income and bringing about wellbeing' (MAPA 2006).

5 The analysis of the implications for smallholders is drawn partly from a report commissioned by FAO and the Brazilian Ministry of the Environment (Miccolis 2008), which analysed the constraints in the Brazilian regulatory framework from the standpoint of smallholders and traditional communities to operate socio-biodiversity production chains.
Meanwhile, the Ministry of Agrarian Development (MDA) has helped to organise crop production - the weak link in the biodiesel chain through five efforts:

1. supporting family farming-based production centres;

2. conducting the agricultural zoning in partnership with MAPA by 2010 ;

3. producing seeds and seedlings;

4. providing technical assistance in coordination with the Biodiesel Thematic Network, which drafts proposals for specific projects through agreements with State-level rural extension agencies and the MDA; and

5. taking stock of oilseed crops in a partnership with the Federal University of Viçosa. The MDA has mapped out the demands for family farming and supported, both directly and indirectly, research aimed at developing solutions and new agroenergy-related prospects for family farming (MDA 2009b).

The MDA is also home to the main bureau dealing with smallholders, the Secretariat of Family Farming (SAF), which set up the Farm-Biodiesel Program (PRONAF: Programa Nacional de Agricultura Familiar [National Family Farming] no Biodiesel MDA 2009a) as a mechanism for including family farming within the biodiesel production chain. PRONAF's overarching strategy is to build the capacity of family farming cooperatives and foster entrepreneurship among smallholders so as to create jobs and generate income in this sector. Ever since PRONAF-Biodiesel was implemented, family farmers account for approximately $15 \%$ of all feedstock used in the Brazilian biodiesel industry. The PRONAF beneficiaries are producers and their organisations, with family farmers classified according to the following criteria: using family-based labour supplemented by temporary workers and a maximum of two full-time employees; possessing or farming a plot of land smaller than four 'fiscal modules' (which may range from 20-100 ha, depending on 
the region and municipality); residing on the rural property or in a nearby rural settlement or town; and, $80 \%$ of income must stem from farm-based, fishing or extractive activities. Compliance with these requirements is verified by the unions (CONTAG), which classify family farmers who wish to take part in PRONAF (MDA 2009b).

\subsubsection{The Social Fuel Stamp}

According to the MDA/SAF, the Social Fuel Stamp is issued to biodiesel producers who purchase a minimum percentage of feedstock from family farmers, depending on the region: $30 \%$ in the Northeast, Southeast and South and $10 \%$ in the North and Mid-West up until the 2009/10 harvest and $15 \%$ as of the $2010 / 11$ harvest (MDA/SAF 2007, MDA 2009b). These biodiesel producers are obliged to sign contracts duly negotiated with the family farmers including a predefined term, purchase prices and readjustment criteria, conditions for delivering feedstock, safeguards on both sides, identification of, and agreement by, a farmers' representative in the negotiations and, lastly, clauses that ensure technical assistance and training for the family farmers. Until the beginning of 2009, the 30 companies that earned the Social Fuel Stamp accounted for more than $90 \%$ of the volume purchased through the ANP bidding process. The public auctions for selling biodiesel set aside $80 \%$ of lots exclusively for producers who hold the stamp, which is therefore deemed essential for ensuring sales. While these companies must in theory meet all these requirements, some studies show that they do not always do so (Repórter Brasil 2009; Abramovay and Magalhães 2007). The stamp entitles producers throughout the country to lower rates on taxes such as PIS/PASEP ${ }^{6}$ and COFINS (Contribution for Funding Social Security) as well as more favourable financing conditions at the Brazilian National Development Bank (BNDES) and its accredited financial institutions, Banco da Amazônia S/A (BASA), Banco do Nordeste do Brasil (BNB), or Banco do Brasil S/A, among others.

6 PIS means 'Social Integration Program' and PASEP means 'Civil Servant Heritage Program', federal taxes aimed at funding social security for private and public sector employees, respectively.

\subsubsection{National Sustainable Oil Palm Production Program}

Recently, oil palm has been thrust into the spotlight as a promising feedstock for biodiesel in the Amazon due to the availability of vast swaths of suitable and degraded lands and the fact this crop is highly labourintensive and produces unparalleled yields of oil per ha.

\subsubsection{National Program for Sustainable Oil Palm Production}

The National Program for Sustainable Oil Palm Production is the most recent and comprehensive federal policy aimed at bolstering oil palm production in Brazil. Besides restricting the expansion of oil palm production to areas already affected by human activity up until 2008, it also prohibits suppressing native vegetation by determining that new plantations can only be established on degraded lands, and sets up special lines of low-interest credit for new plantations (SRA 2005). Bill of Law No.7326, which was drafted in 2010 but is yet to be approved by two Congressional Committees to come into legal effect, sets up this national programme as well as guidelines for the Agroecological Zoning of Oil Palm.

The zoning is a planning instrument to ensure that oil palm expansion is underpinned by economic, social and environmental sustainability based on technical and scientific parameters. It excludes areas with intact native vegetation and protected areas, including conservation units and indigenous lands. It determines that only land converted up until 2008 will be eligible for expansion, except for areas aimed at meeting the demands of industrial units that obtained licences before this law was promulgated. The law further establishes low-interest credit lines specifically geared to oil palm for smallholders and commercial farmers, and sets up instruments to promote land and environmental regularisation. The extent to which these policies are enforceable on the ground, especially in the Amazon, remains to be seen, however, due to underlying logistical constraints and lack of government resources. Furthermore, as discussed below, the lack of access to land tenure, environmental licensing procedures and rural credit and extension services by smallholders and traditional 
communities may stand as significant obstacles for oil palm expansion to be as truly sustainable and socially equitable as the Government intends.

\subsection{The Brazilian environmental and legal framework relevant to biofuels}

The Brazilian environmental legal framework is deeply rooted in a series of laws, statutes and environmental management systems generally considered to be quite advanced and relatively strict compared to most other countries. However, many of these ambitious policies on paper are very difficult to enforce in practice. The 1988 Constitution itself devotes an entire chapter to the environment but many of its provisions have yet to be adequately regulated by specific laws. As a basic constitutional principle, government services such as education, healthcare and environmental regulations must be decentralised to the State and municipal level, yet local governments often lack the wherewithal to provide these services on large expanses of land and to isolated communities. Indeed, just applying the basic tenets of the Forest Code can be an enormous challenge given the long distances, precarious infrastructure in some regions, and low capacity among environmental agencies in poorer States to enforce basic requirements such as legal reserve set-asides, Permanent Preservation Areas and environmental licences.

Some key laws still governing environmental, land use and tenure issues actually precede the 1988 Constitution, such as the landmark National Environmental Policy passed in 1981 under the military dictatorship, and the Forest Code, which dates back to 1964 and is currently under review (see Table 1). The outcome of this review is likely

Table 1. Environmental regulation legal framework

\begin{tabular}{|c|c|c|}
\hline Law & Description & Regulatory area \\
\hline $4771 / 65$ & Forest Code & Permanent Preservation Areas \\
\hline $997 / 76$ & Environmental Pollution Control & Environmental permission \\
\hline $\begin{array}{l}\text { Portaria do Ministério do interior } \\
323 / 81\end{array}$ & $\begin{array}{l}\text { Prohibits the release of vinasse in } \\
\text { rivers }\end{array}$ & \\
\hline $6938 / 81$ & National Environmental Policy & Mechanisms and instruments (EIA- EIAR) \\
\hline CONAMA deliberation 0001/7986 & General guidelines of the EIA & For industry and agroindustry \\
\hline $6171 / 88$ & Soil conservation in agriculture & \\
\hline $11241 / 02$ & Sugarcane Burning Phasing out & $\begin{array}{l}\text { Gradual elimination of fire in sugarcane } \\
\text { harvesting }\end{array}$ \\
\hline $12183 / 05$ & Water Code & \\
\hline $50889 / 06$ & Legal reserve in São Paulo State & $\begin{array}{l}\text { Obligation of reserving an area } \\
\text { equivalent to } 20 \% \text { of rural property }\end{array}$ \\
\hline SMA deliberation n42/06 & $\begin{array}{l}\text { Prior Environmental Licence for } \\
\text { sugarcane farms, ethanol distillers } \\
\text { and mills }\end{array}$ & It defines criteria and procedures \\
\hline Deliberation 383/06 & Deliberates limits of emission & Anxex 3 - sugarcane air emissions limits \\
\hline $\begin{array}{l}\text { Agriculture and Environmental } \\
\text { Protocol }\end{array}$ & $\begin{array}{l}\text { Anticipation of elimination of and } \\
\text { phasing out of burning }\end{array}$ & UNICA and São Paulo State government \\
\hline $\begin{array}{l}\text { SIAMIGa protocol elimination of } \\
\text { sugarcane burning }\end{array}$ & $\begin{array}{l}\text { Removal of burning by } 2014 \text { in } \\
\text { Minas Gerais State }\end{array}$ & \\
\hline Decree 6680/08 & Environmental Crime Law & $\begin{array}{l}\text { Will come into effect in } 2011-2012 \\
\text { and will impose fees and bills against } \\
\text { noncompliance }\end{array}$ \\
\hline
\end{tabular}

a Minas Gerais State Union of Ethanol Manufacturers (Sindicato da Indústria de Fabricação do Álcool no Estado de Minas Gerais) 
to have wide-reaching impacts on land availability for cultivating energy crops in Brazil, particularly in ecoregions such as the Amazon tropical forest and Pantanal wetlands, where at least $80 \%$ of all rural land is set aside as legal reserves under current legislation.

Environmental regulation and enforcement has evolved considerably over the past few decades in Brazil, from command and control-oriented tactics to a more comprehensive approach, including socioeconomic, biodiversity and cultural issues. The National System of Conservation Units (SNUC) sets out a wide range of protected areas, from 'full protection units', such as National Parks and Biological Reserves, to others where certain land use types are allowed, such as Sustainable Development Reserves (RDS) and Extractivist Reserves (RESEX). Moreover, through programmes such as Arco Verde Terra Legal (see Box 1), the focus has shifted away from command and control-oriented policies to tackle the underlying causes of deforestation, such as lack of land tenure and effective environmental licensing mechanisms.

This section describes the wider environmental Brazilian policy framework affecting biofuels expansion. This framework is divided into three main categories for our analysis: 1) environmental regulations, including the Forest Code, licensing procedures, and environmental preservation requirements; 2) FDI and land availability and acquisition procedures; and, 3) agricultural and rural development policies, such as land tenure, agricultural research, technical assistance and rural extension policies and programmes.

\subsubsection{Environmental licensing}

Under the National Environmental Policy (Law 6938, 1981), which was regulated by a series of National Environmental Council (CONAMA) resolutions, environmental licences are required for potentially polluting or environmentally damaging activities such as processing plants, distilleries, refineries or high-impact agricultural activities (Figure 3). These activities must undergo a licensing process divided into three steps:

1. Prior Licence, by which the authority confirms the environmental feasibility of the undertaking or activity and establishes basic requirements and terms to be complied with during the subsequent implementation stages;

2. Installation Licence, by which the authority approves the initial implementation of the undertaking or activity in accordance with the specifications in the plans, programmes and projects approved; and

3. Operating Licence, which the authority issues once the undertaking or activity has effectively complied with the conditions laid out by the former licences.

Deforestation and the use of fire as a cropping technique also require official authorisation. While enforcement of environmental regulations in general has increased substantially over the last few years due to numerous federal and state programmes, São Paulo State has made licensing procedures for ethanol distillers easier by setting up a Prior Environmental Report (RAP), a faster track than the more cumbersome Environmental Impact Assessment (EIA) required under federal law. This fast track bypasses the usual environmental review process, which has given rise to concerns among environmental groups and some government agencies.

In 1997, CONAMA Resolution 237/1997 set the criteria for issuing environmental licences for biofuels production, whenever the installation, operation or expansion of such projects involves the use of environmental resources, is considered to be polluting, or may cause environmental damages.

In order to meet the Government's obligation of publicising the prior Environmental Impact Assessment (EIA) study and ensuring public consultation (Constitution, Art. 225 and CONAMA Resolution 237/1997), under this procedure, public hearings are mandatory and can be summoned under four situations:

- whenever the environmental authority deems necessary;

- by request of civil organisations;

- by request of the public prosecutor's office (Ministério Público); and,

- by request of 50 or more citizens. 
In São Paulo State, the São Paulo State Environment Secretariat's SMA Resolution no. 42/94 determined that the Preliminary Environmental Report (RAP) is enough for obtaining the Prior and Installation Permit for new sugarcane and ethanol mills with a capacity higher than 1.5 million tonnes of milled sugarcane/year, thus foregoing the federally mandated EIA. Furthermore, SMA Resolution 14/2005 determines that below 200000 tonnes of milled sugarcane/year, mills do not require a RAP to obtain Prior, Installation and Operating Permits. However, this resolution does not take into account environmental risks associated with the location of ethanol distillers, nor does it bear in mind the production chain and logistics as a whole, including ethanol pipelines.

\subsubsection{Presidential Decree 6961/2009 and São Paulo State law SMA-SAA (2008)}

The Agroecological Zoning for Sugarcane (National ZAE) and São Paulo State Agro-environmental Zoning (SMA ZAE) laws for sugarcane and ethanol mills emerged as unprecedented government initiatives to define priority areas for expanding agricultural activities in light of crop suitability and environmental concerns. Both national and Sáo Paulo ZAEs oversee a database used for spatial planning and sustainable cultivation of sugarcane fields based on current preservation laws and environmental risks. The National ZAE, see Table 2, which was led by the Ministry of Agriculture, indicates that if Brazilian sugarcane production doubles by 2017, the total cropland area is bound to reach 15.5 million ha by 2017 (see Figure 2). Based on key parameters such as environmental concerns, climatic suitability and soil conditions, this zoning has determined that $92.5 \%$ of the national territory should not be used for sugarcane cultivation, thereby excluding the Amazon and Pantanal (wetlands) biomes. Thus, the Cerrados of South-Central Brazil are currently the key foci for sugarcane expansion.

The São Paulo ZAE is geared towards environmental licensing of new sugarcane fields and mills, and provides a regulatory procedure and restrictions on the expansion of sugarcane ethanol production in the whole State, based on federal and State laws. In the São Paulo ZAE (Figure 3), red is the prohibited zone, yellow is considered suitable albeit with environmental 'restrictions', light green zones are suitable but face environmental 'limitations', and deep green is considered suitable and appropriate for ethanol expansion.

\subsubsection{The Forest Code, the social function of land and protected areas}

As early as the 1960s, two landmark laws, the Land Statute (Estatuto da Terra 1964) and Forest Code (Código Florestal 1965), laid out the notion of the 'social function' of land based on four criteria later set in stone in the 1988 Constitution: a) productivity; b) compliance with labour laws; c) environmental preservation; and, d) wellbeing and health of landowners and their workers. This notion is the key

Table 2. National ZAE for sugarcane in Brazil (MAPA 2008)

\begin{tabular}{|c|c|c|}
\hline Territory or estimated area & Million ha & $\begin{array}{l}\text { Portion of national } \\
\text { territory }(\%)\end{array}$ \\
\hline National territory ${ }^{\mathrm{a}}$ & 851.5 & 100.00 \\
\hline Agriculture lands & 553.5 & 65.00 \\
\hline Land in use in $2002^{\mathrm{b}}$ & 235.5 & 27.70 \\
\hline Environmentally restricted areas & 694.1 & 81.50 \\
\hline $\begin{array}{l}\text { Suitable areas currently being used by agriculture and livestock } \\
\text { production }\end{array}$ & 64.7 & 7.50 \\
\hline Suitable areas currently being used for pasture & 34.2 & 4.02 \\
\hline Areas currently under sugarcane $2008 / 2009^{c}$ & 7.8 & 0.90 \\
\hline Expansion of sugarcane production foreseen for $2017^{d}$ & 6.7 & 0.80 \\
\hline
\end{tabular}

Sources: a. IBGE (Brazilian Institute of Geography and Statistics) b. PROBIO (Activity of the Program for Conservation and Sustainable Use of Brazilian Biologial Diversity) c. CONAB(2008b) d. Adapted from EPE (2009). All other data from MAPA (2008). 




Figure 2. Potential ethanol expansion in Brazil in 2010

Source: Repórter Brasil (2009) 


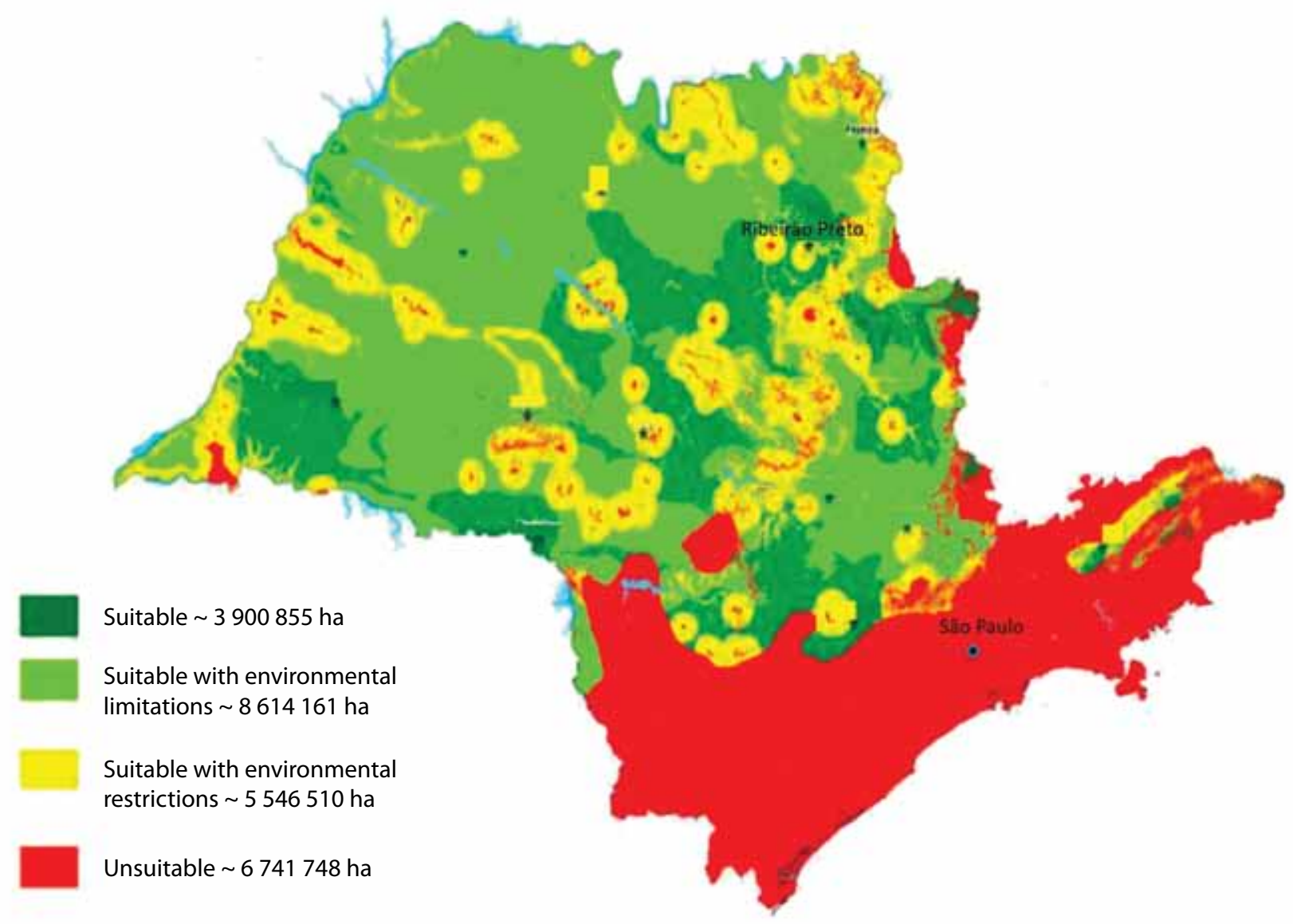

Figure 3. São Paulo State ZAE for sugar ethanol expansion

Source: SMA (2008)

to understanding both agrarian and environmental policies in Brazil, since it determines that rural property must benefit society at large, not only those who own it. So land considered idle because it is not being used for farming may be expropriated for agrarian reform purposes. Moreover, all rural properties must set aside a percentage of land as 'legal reserves' where the native vegetation must be preserved under the Forest Code. This law also determined that the banks of all water bodies (rivers, lakes, streams, springs), as well as steep hillsides and ridges must also be preserved in Permanent Preservation Areas (PPAs). The distance from either side of riverbanks that must be left intact, which varies according to the width of the river, ranges from 30 to 500 metres.

Currently, the percentage of legal reserve required varies per ecoregion in Brazil, from $80 \%$ in the Amazon biome, 35\% in stretches of Cerrado (Brazilian savannah) within the 'Legal Amazon', and
$20 \%$ throughout the rest of the country. Upon issuing new land titles, landowners are obliged to map out and commit to preserving - and recovering in the case of degraded lands - these two parts of their land (Política Nacional de Meio Ambiente 1981).

While these legal provisions are extremely difficult to enforce in vast swathes of hard-to-reach lands, especially in the Amazon, they do act as substantial constraints on expanding biofuels in the North and parts of Mid-Western Brazil, where the 'Legal Amazon' is located (Arco Verde Terra Legal 2009; Miccolis 2008). In São Paulo State, many sugarcane and ethanol producers are hard pressed to meet this legal requirement due to a lack of land available for legal reserves so they face a serious environmental liability that might only be solved by paying for offsite legal reserve set-asides.

The Forest Code has become a serious liability issue in São Paulo State and beyond, where the majority 
of sugarcane growers and ethanol producers have not complied with the Code and charges have consequently been filed against them (Leão 2008; Brancalion and Rodrigues 2010). In 2008, IBAMA, the Brazilian Institute for the Environment and Renewable Natural Resources, fined 24 sugarcane and ethanol plants from Pernambuco State a total of R120 million (R5 million each) and their owners were indicted on criminal charges and faced civil lawsuits because of noncompliance. The environmental liability pertaining to sugarcane and ethanol plants is estimated at 85000 ha of forest in Pernambuco State alone. Settling environmental liability by recovering legal reserves may be done on the properties or ex-situ (by recovering other areas outside the property), provided it is in the same watershed and approved by IBAMA. In Sáo Paulo alone, the cost of restoring agricultural land back to native vegetation is estimated at 37 billion reais. Even large business groups waving the flag of sustainability in agribusiness are illegal, according to the Forest Code (Leão 2008). The Balbo group, a São Paulo-based company that owns the brand Native, a pioneer in the organic sugar industry, is facing 24 lawsuits due to noncompliance on legal reserve and Permanent Preservation Area requirements. According to an assessment by the Luiz de Queiroz (ESALQ/USP) College of Agriculture Environmental Program at the University of São Paulo, the average legal reserve in São Paulo cane mills ranges from $8 \%$ to $12 \%$, which is only half of the $20 \%$ required by the Environmental Code for the South-East (Brancalion and Rodrigues 2010). ESALQ/UNICA and the Organisation of Sugarcane Planters of the State of Sáo Paulo (ORPLANA) have been working on a project to install reforestation projects in 1.8 million ha in São Paulo, which includes lands associated with 33 mills. Moreover, UNICA and ORPLANA are lobbying the Federal Government to prevent Decree 6.686/2008 from coming into effect, since this law, which regulates the Environmental Crimes Law, instituted a 120-day deadline for landowners to register legal reserves occupying $20 \%$ of their properties, or else face fines.

Efforts are underway in the National Congress to reduce the minimum legal reserve set-aside and allow cultivation of exotic species such as oil palm in these protected areas. If approved, these measures might drastically increase the land available for cultivating oil palm and other feedstock in the Amazon, potentially altering the pristine rainforest environment and landscape. An estimated 80 million ha of new land could be deforested due to a measure effectively reducing the amount of protected areas required on small plots, according to recent Ministry of Environment estimates. Moreover, according to a University of São Paulo study, a further 65 million ha might lose protection because of a provision in the bill currently going through the national legislature that overlaps PPAs and legal reserves for the purposes of accounting protected areas (Sassine 2010).

\subsubsection{Management plans}

In the case of Conservation Units, public forests, and other Protected Areas (PPAs and legal reserves) on rural properties, altering the vegetation or commercial extraction of native species requires drafting management plans through participatory processes conducted by technically qualified staff. From the smallholders' standpoint, these are considered lengthy and costly processes that lack clear technical and practical guidelines (Miccolis 2008).

\subsubsection{São Paulo State Law 11241/2002 - the sugarcane burning phasing out in São Paulo State}

In 2002, pressured by public opinion, the media, the Public Attorney's Office, and environmental and human rights movements, legislators drafted a bill to ban sugarcane-related burning altogether. In practice, this entails resorting to mechanised harvesting of the 'raw' sugarcane, a more cost-effective technique than manual harvesting. ORPLANA and UNICA lobbied intensely for gradually phasing out burning, claiming an outright ban would create a wave of unemployment and deal a serious blow to the ethanol/sugarcane sector, which was still struggling to recover from a long downturn. (Andrade and Miccolis 2010a)

Ultimately the law determined that growers must reduce the percentage of burnt plantations gradually so as to eliminate this practice by 2021 , in areas where mechanised harvesting is feasible, and by 2031 in areas where mechanisation is not considered feasible (i.e. with slope $>12^{\circ}$, on plots below 150 ha, or where soil conditions are unfavourable). 


\subsection{Foreign Direct Investment - FDI legal framework}

By and large, Brazil's Foreign Direct Investment (FDI) policies and legal framework are considered quite liberal, since over the past few decades they have not set up significant legal or fiscal barriers to FDI in all but a few sectors. Under federal law, FDI receives the same legal status as national investments, which means that foreign capital is not entitled to any special advantages, only the same benefits afforded to nationallyowned companies. The only requirement for foreign-owned companies is to register their investments and reinvestments of profits through the Central Bank's Foreign Capital Registry, as set out by Central Bank Resolution 3844. Certain restrictions do apply to sectors considered strategic, such as mining, healthcare and hydrocarbons, but not to all other economic activities, including biofuels. On the other hand, Brazil offers investment incentives to specific industries, for investments in less developed regions and in tax-exempt exportoriented sectors. Additionally, the Foreign Trade Chamber (CAMEX), which is led by a council of seven ministers, publishes resolutions granting low tariffs (4\%) for equipment imports that could not otherwise be produced in Brazil (MDIC 2010).

Historically, FDI in Brazil was fueled by investments in the industrial sector in the 1930s and 1950s. Since the mid-1990s, investments in Brazilian agribusiness and agroenergy have risen sharply due to factors including large expanses of fertile land available and suitable for producing commodities year-round; highly developed agricultural technologies such as new crop varieties aimed at exports, including soybeans, corn, sugarcane, and beef; the rising global demand for food and biofuels; and, the robust macroeconomic and monetary situation in Brazil. According to the Brazilian Central Bank, from 2002 to 2008, US\$46.9 billion was invested in rural activities in Brazil, which accounted for $29.5 \%$ of the country's overall FDI during this period (BCB 2009).

FDI requirements in Brazil have become increasingly liberalised over the past few decades. A constitutional amendment passed in 1995 eliminated the distinction between foreign capital and national capital for legal purposes and, in 2000, a National Monetary Council Resolution (No.2689) significantly reduced bureaucratic hurdles to foreign investment. Nowadays, investments, redemption, earnings, capital gains, transfers and other movements of foreign portfolio investments are subject only to electronic declarations, for monitoring purposes.

\subsubsection{FDI and taxes in Brazil}

As outlined above, foreign direct investment in Brazil is totally exempt from income tax, although goods such as machinery and equipment transferred to the country from abroad are subject to import taxes, a Tax on Industrialised Products (IPI), and a valueadded tax (ICMS), as well as customs fees. While national and foreign capital invested in Brazil have the same status under Law 4131/62, profits earned by foreign residents are exempt from income tax, since the main criteria is whether the person/company resides or is headquartered abroad. Interest earned by foreigners living in Brazil or companies based in Brazil, however, is taxed at 15\% (Art. 668 of Income Tax Regulation RIR/99 and Art. 2 of Circular Bacen n. 2.72/96). Similarly, capital gains earned by foreigners living in Brazil or abroad are taxed at $15 \%$. Here, one must underscore that Brazil has bilateral agreements with a whole host of countries aimed at avoiding double taxation for some of these taxes. Decree 3.000/99, known as the RIR/99, lays out several provisions for taxing income from foreign investments in Brazil.

The other main taxes worth highlighting are federal income taxes, value-added taxes and social welfare taxes (Table 3). Federal income taxes are levied on businesses and individuals set up in Brazil (corporate income tax, IRPJ, and individual income tax, IRPF). Value-added taxes include the ICMS and IPI ${ }^{7}$. Social taxes include CSLL (Social Contribution on Net Profits), PIS (social security tax for private sector employees) and PASEP (social security tax for civil servants)as well as the social security tax (INSS) that applies to all workers. The ICMS is a State-level value-added tax usually fixed at $18 \%$ but specific rates apply to specific goods (i.e. $25 \%$ for luxury goods and $7 \%$ on basic food products) and vary per State. Some States have offered hefty tax incentives to sectors such as the automobile industry and technology-oriented companies in 'tax wars' aimed at attracting investors. Other taxes levied by municipal governments include property taxes.

7 ICMS: Imposto sobre Circulação de Mercadorias e Serviços, a value added tax and IPI, industrial production tax). 
Table 3. Taxes in Brazil

\begin{tabular}{lcl}
\hline Tax or mandatory contribution & Statutory tax rate (\%) & Tax base \\
\hline ICMS (similar to VAT) & 18.0 & value added, including taxes \\
IPI (similar to VAT) & 20.0 & value added, including taxes \\
PIS/COFINS (similar to VAT) & 9.3 & value added \\
Social security contributions (INSS) & 20.0 & gross salaries \\
Corporate income tax (IRPJ) & 15+10, with surcharge on & taxable profits \\
& annual taxable income above & \\
Payroll tax & R 240 000 & gross salaries \\
Severance contribution (FGTS) & 8.8 & gross salaries \\
Social contribution (CSLL) & 8.5 & taxable profits \\
Property tax & 9.0 & market value of property \\
Financial transactions tax (CPMF) & 2.5 & bank transactions \\
Tax on interest & 0.4 & interest income \\
Vehicle tax & 20.0 & market value of vehicle \\
\hline
\end{tabular}

Source: adapted from World Bank (2010)

\subsection{Overall agricultural and rural development policies}

On the one hand, agricultural research in Brazil, most notably through Embrapa (the publically owned National Agricultural and Livestock Research Corporation) has undeniably revolutionised Brazilian agriculture over the last 30 years. The research effort has increased yields dramatically and developed crop varieties better adapted to the poor soils and lower rainfall of Brazil's central savannahs. This has enabled the spread of cash crops such as soy, corn and sugarcane in regions that would otherwise be unsuitable (Hall et al. 2009). Generally speaking, though, smallholders are not in a position to reap the fruits of these high input and large scale agricultural systems because they lack the financial means to access credit, sufficient scale to compete with large scale farmers, and technical knowhow and support to adequately manage these systems (Wilkinson and Herrera 2008; Miccolis 2008).

While the Federal Government has greatly increased direct funding for family farming through the National Family Farming Program, from around $\mathrm{R} \$ 2$ billion in 2003 to $\mathrm{R} \$ 16$ billion in 2010/2011 (MDIC 2010), this amount is still relatively small as compared to the $\mathrm{R} \$ 100$ billion invested in rural credit for corporate farming during the same period. So while policies targeting family farmers have grown enormously over the past 10 years, and while this sector is a key for food production in Brazil, family farmers are still at an enormous disadvantage compared to corporate farmers, as seen in sections 4.8 through 4.10 below.

\subsection{Access to natural resources}

Several new biodiesel feedstocks that Brazilian researchers have been studying entail harvesting from palm trees, nuts or other native oilseeds growing in the wild. Although indigenous communities are entitled by law to harvest the natural resources found on their own reserves, other traditional communities such as fisherfolk, riverine and forest-dwelling communities lack land titles, so they are much less inclined to make long term investments in expanding primary production or processing. In certain regions, conflicts over the use of natural resources have given rise to strife and hindered poor peoples' access to native palm tree resources, even when such access is guaranteed by law (Repórter Brasil 2008a, 2008b, 2009). An example is the Movement of Babassu Nut Breakers (Movimento das Quebradeiras de Coco de Babaçu), which has managed to get municipal and State legislation passed entitling them to harvest the nuts from this palm tree regardless of where the trees are found. In many regions, however, conflicts surrounding access to babassu groves still abound.

On the other hand, in order to address this problem, some recent Federal Government policies targeting 


\section{Box 1. Arco Verde Terra Legal Program [Green Arc Legal Land Program]}

Throughout the last 50 years, the population in the Brazilian Amazon has grown 20-fold thanks to intense waves of migration by settlers and squatters from various parts of the country. These migrants were attracted initially by ambitious government settlement policies during the 1970s aimed at boosting economic development through farming, livestock, timber and mining activities. This wave of demographic growth brought rising land tenure irregularities and ensuing deforestation of the rainforest through uncontrolled land use practices (Arco Verde Terra Legal 2009).

In order to address this situation, the Federal Government created the Green Arc Legal Land Program (PTLA) in 2009 with the aim of issuing land titles to legitimate settlers in the Amazon region (Arco Verde Terra Legal 2009). While millions of people in Brazil legitimately occupy lands without titles, especially in the Amazon region, the lack of land tenure in Brazil and tenure irregularity is deemed a major obstacle for implementing various governmentbacked development programmes (including the PNPB) and for stopping deforestation and unplanned land use. The PTLA's goal is to remove this barrier by enabling land regularisation, especially in subregions with high deforestation rates, thus also widening opportunities for establishing agroenergy in the region.

This programme is a multisectoral effort involving the following ministries and associated agencies: Agriculture (Embrapa, National Supply Agency (CONAB) and the Cocoa Development Agency(CEPLAC); Social Security Agency (INSS); Ministries of Cities; Culture; Defence; Education, Labour and Employment; Secretariat of Federal Assets; Special Secretariat for Aquiculture and Fishing; Special Secretariat for Human Rights; Banco do Brasil, Banco da Amazônia; Brazilian National Development Bank; Brazilian Service of Support for Small and Medium Enterprises (SEBRAE), as well as municipal and State governments in Mato Grosso, Pará, Maranhão, Roraima, Rondônia and Amazonas states.

For the purposes of biodiesel production, the programme aims to open up opportunities for planting oilseed crops in areas where farmers did not have access to public financing programmes, fiscal incentives and technical assistance. Judging by Brazilian Federal Government policies within the PNPB - and those put forth by State governments such as Pará and Amazonas, as well as by private sector trends discussed above - oil palm will be the main crop receiving fiscal incentives, research and investments aimed at expanding production in the Amazon. Thus, oil palm is clearly being touted as the main oilseed for supporting the expansion of biofuels in northern Brazil (NAE 2004; COPPEAD 2007).

Source: Andrade and Miccolis 2010b; Arco Verde Terra Legal 2009

smallholders and traditional communities ${ }^{8}$ have been increasing access to biodiversity, which may prove highly relevant for several oilseeds, by allowing planting of exotic species in PPAs and legal reserves, provided they do not significantly alter the biophysical characteristics typical of that ecoregion. While it is subject to change under the new Forest Code, this measure alone will go a long way to extending the area available to smallholders for planting short cycle oilseed crops and perhaps even perennial species such as oil palm.

\subsection{Land tenure}

A major obstacle to obtaining legal access to natural resources, including land, water and forests, is the extremely chaotic land tenure situation in

8 Two CONAMA resolutions passed in 2009 and 2010 have allowed such use of preservation areas for the first time since the Forest Code was approved in 1964. many parts of rural Brazil. Communities that have been occupying and farming lands - in some cases for generations - but do not hold land titles are, in practical terms, excluded from many rural development policies such as rural credit and environmental licences, since proof of officially recognised ownership or authorised use is a basic eligibility requirement. Even for large landholdings, confusing land tenure can be a significant hurdle because land considered to be idle may be expropriated for land reform, or claimed by squatters or families living on the land. In an attempt to tackle this problem, the Federal Government launched the multiministry programme known as Arco Verde Terra Legal, or the Green Arc Legal Land Program (Box 1).

\subsection{Land acquisition and availability}

Up until very recently, there were no restrictions on foreign individuals or companies wishing to purchase land in Brazil. Over the last five years, several factors 
have contributed to a controversial land grab in Brazil, which has the largest agricultural frontier in the world with approximately 130 million ha that can be used for agriculture. In the wake of the global financial crisis and amid growing demand for foodstuffs, biofuels and relatively cheap arable land, a huge influx of foreign capital has been buying up land and raising eyebrows in Brazil. In August 2010, this land grab prompted the Brazilian Attorney General's Office (Advocacia Geral da União AGU) to issue a ruling signed by President Lula that prohibits foreign individuals - or companies controlled by foreign capital - from acquiring land larger than 5000 ha or which accounts for more than $25 \%$ of the municipality. According to the AGU, the lack of control over land acquisitions has contributed to rising land prices, speculation on public lands, as well as land purchases in border regions, which undermines national security (INCRA 2009). This recent ruling emerges from a reinterpretation of a Law passed in 1971 under the military regime, which was underpinned by notions of national sovereignty and security, and its provisions are currently being considered for a constitutional amendment.

One of the main drivers for Brazil's colossal rise over the past 30 years to top producer of several agricultural commodities has been the availability of vast expanses of land suitable for large scale farming using 'green revolution' technology. Indeed, Brazil's Cerrado biome (central savannahs), which is found in nine states but largely concentrated in the MidWestern region, is being rapidly converted not only to vast soybean, cotton and corn plantations, but also to sugarcane production.
Over the past 30 years, foreign investors have been buying up Brazilian land at phenomenal rates. According to INCRA (2009), the National Colonization and Land Reform Institute data, 4.3 million ha are registered through public notaries as being foreign-owned, although actual figures may be two to four times higher due to widespread underreporting, since registration by notaries has not been required for the last 15 years. Thus, an estimated 10 million ha in Brazil, or more, is estimated to be foreign-owned.

Recently, China has been one of the main land buyers in Brazil, especially in western Bahia, where it has recently signed agreements to purchase 200000 ha to 250000 ha for food production. The main States where foreigners have been buying up large tracts for agribusiness are in the central savannas of Brazil's Mid-West and in the so-called MAPITO region, comprised of the States of Maranhão, Piauí and Tocantins. This land grab also coincides with the new frontier of sugarcane-ethanol production, which has been expanding most rapidly in the Mid-Western states of Goiás and Mato Grosso do Sul, as well as in Bahia, Mato Grosso and Alagoas (Abramovay 2008).

\subsubsection{The expansion of sugarcane ethanol and biodiesel crops}

The 2030 National Energy Plan projects that sugarcane will expand to 13.9 million ha by 2030 (Table 4), $84 \%$ of which will be in the Central-South region where the Cerrado biome is located.

Likewise, the estimated impacts of blending 5\% biodiesel into the diesel consumed in Brazil shows

Table 4. Production, planted area and productivity of sugarcane (EPE 2009)

\begin{tabular}{|c|c|c|c|c|c|c|c|}
\hline & & 2005 & 2010 & 2015 & 2020 & 2025 & 2030 \\
\hline \multirow[t]{3}{*}{ Brazil } & Production ( $10^{6}$ ton) & 431.4 & 518.4 & 715.0 & 849.2 & $1,002.0$ & $1,141.2$ \\
\hline & Area $\left(10^{6} \mathrm{ha}\right)$ & 5.6 & 6.7 & 9.2 & 10.6 & 12.4 & 13.9 \\
\hline & Productivity (ton/ha) & 76.6 & 77.0 & 78.1 & 80.1 & 80.8 & 82.1 \\
\hline \multirow[t]{3}{*}{ Centre-South } & Production (10 ton) & 373.7 & 445.6 & 600.1 & 712.8 & 838.0 & 957.9 \\
\hline & Area $\left(10^{6} \mathrm{ha}\right)$ & 4.6 & 5.5 & 7.4 & 8.7 & 10.2 & 11.6 \\
\hline & Productivity (ton/ha) & 80.5 & 80.6 & 81.1 & 81.9 & 82.2 & 82.9 \\
\hline \multirow[t]{3}{*}{ Northeast } & Production (10 ton) & 57.7 & 72.8 & 114.9 & 136.4 & 164.0 & 183.3 \\
\hline & Area $\left(10^{6} \mathrm{ha}\right)$ & 1.0 & 1.2 & 1.8 & 1.9 & 2.2 & 2.4 \\
\hline & Productivity (ton/ha) & 58.0 & 60.6 & 65.6 & 71.8 & 74.5 & 78.0 \\
\hline
\end{tabular}


that soybeans will certainly continue to be the main source of vegetable oil for producing biodiesel, since using other feedstocks to meet this demand would require astronomical increases in cropland (Table 5) (Souza 2009).

Table 5. Estimated impact that blending $5 \%$ biodiesel into diesel will have on land under selected crops, based in 2009 levels

\begin{tabular}{lc}
\hline Crop & $\begin{array}{l}\text { Area (ha) } \\
\text { Increase (ha) } \\
\text { Impact (\%) }\end{array}$ \\
\hline Soybeans & 1534300 \\
& 3408885 \\
& 18.39 \\
\hline Sunflower & 43200 \\
& 3097981 \\
& 7171.25 \\
\hline Cotton & 739200 \\
& 4437500 \\
Castor beans & 600.31 \\
\hline Oil palm & 128000 \\
& 2454787 \\
& 1917.80 \\
\hline Sugarcane & 45000 \\
& 307,667 \\
& 683.70 \\
\hline
\end{tabular}

Source: CONAB (2008a, 2008b), IBGE (Brazilian Institute for Geography and Statistics, calculations from FAESP (São Paulo State Federation of Agriculture) Economic Department, adapted by Souza (2009)

\subsection{Structural constraints for smallholders and traditional communities}

Despite notable progress in Brazil over the last decade to include the rural poor in environmental and agrarian policies and programmes, with considerable effort to adapt norms and procedures to the peculiarities of family farmers, the rural development model that still prevails in many regions is much more geared towards cultivating commodities on vast landholdings (Hall et al. 2009). While some ambitious programmes such as the National Family Farming Program (PRONAF) have made available huge amounts of low-interest credit for smallholders, recent studies have shown that biodiesel production may follow a similar path of concentration witnessed in the case of sugarcane (Abramovay 2007).
Some key policies aimed at granting smallholders and traditional communities access to natural resources and rights include Sustainable Use Conservation Units; laws ensuring traditional rights to genetic heritage; benefit-sharing; forest concessions; and, rural development policies, including targeted credit programmes. According to a wide-reaching consultation process involving representatives of traditional communities and family farmers analysed by Miccolis (2008), these communities do not manage to abide by environmental and marketing regulations because they do not have access to information presented in a way they can understand or due to their low level of social organisation, technical qualification and formal knowledge. Conversely, representatives of smallholders and NGOs underscored that government officials lack clear guidelines for interpreting laws and regulations and adapting them to the local reality of rural communities.

Furthermore, the barriers to effectively implementing environmental and rural development policies in the context of smallholders may be attributed to the low institutional capacity of government agencies in terms of technical, human and financial resources to implement these policies, especially with regard to environmental licensing, rural credit and market access.

Indeed, this multistakeholder process concluded that government field staff often lack the necessary skills to implement the principles and procedures laid out in policies through participatory methodologies, knowledge management and sustainable farming systems.

Under the 1988 Constitution, federal policies such as environmental, health, education and rural extension were decentralised to the State and municipal level. However, State and local governments often lack the capacity to implement and monitor these policies, so service provision to rural populations in many regions is seriously undermined in quantity and quality, specially the North, Northeast and parts of the Mid-West (Miccolis 2008).

So this complex set of policies and procedures stands as a significant barrier for smallholders to add value to feedstock and render production chains more vertical. Since it is much easier for large scale 
producers to meet these requirements, family farmers are often relegated to simply supplying raw materials for biofuels, in which case they still face difficulties competing with large scale monocrop plantations. At the end of the day, many smallholders find themselves having to find work in neighbouring farms rather than producing feedstock on their own properties. This ultimately undermines their livelihood strategies, contributing to greater land concentration and migration (Repórter Brasil 2009). In order to tackle these constraints, since the late 1990s the Federal Government has drafted and implemented policies geared towards smallholders in special categories known as 'family farmers' and 'traditional communities'.

\subsection{Policies targeting family farmers and traditional communities}

While family farms in Brazil occupy only $24 \%$ of farmland, they produce $87 \%$ of all cassava, $70 \%$ of beans, $46 \%$ of corn, $38 \%$ of coffee, $34 \%$ of rice, $58 \%$ of milk, $59 \%$ of pork, $50 \%$ of poultry, $30 \%$ of cattle, $21 \%$ of wheat and $16 \%$ of all soybeans produced in Brazil (MDA 2010). Moreover, family farms account for $84.4 \%$ of all rural properties (MDA 2009b); IBGE 2006) Thus, family farmers are vital for food production and, increasingly, the Federal Government has drafted specific policies to include them in biofuel feedstock production.

Indeed, ever since the 1990s, the Federal Government has drafted overarching policies and programmes targeting family farmers and traditional communities, most notably: the I and II National Agrarian Development and Land Reform Policy, the National Socio-biodiversity Plan, PRONAF (National Family Farming Program), and several specific programmes managed by line ministries and agencies, including the National Technical Assistance and Rural Extension Policy, and the Food Procurement Program. While some programmes cut across sectors, the main champions of family farmers and traditional communities during the two terms of the Lula Administration have been the Ministry for Agrarian Development (MDA) through the Secretariat for Family Farming (SAF) and the Ministry of the Environment (MMA), through the Agroextractivism Secretariat, as well as the Ministry for Social Development, which manages a widereaching, direct cash-transfer programme known as Family Stipend (Bolsa Família). These three ministries support multistakeholder participatory processes (including the six seminars mentioned above) through which the sociobiodiversity and land reform plans were designed, and they continue playing a key role in implementing and monitoring the actions within these wider programmes.

As discussed in our analysis of the key policies in the biodiesel sector, the main programme for promoting smallholder inclusion (the Social Fuel Stamp within the $\mathrm{PNPB}$ ) in the biodiesel production chain requires suppliers to purchase a minimum percentage (which varies per region) of their raw materials from familybased farmers and provide technical support, as well as other provisions aimed at ensuring fair trade, such as negotiated prices and guaranteed purchase agreements. However, these clauses are difficult to enforce and are not focused on building the capacity of smallholders to compete with large producers and upscale sustainably, or to form horizontal linkages in this first stage of the supply chain (Wilkinson and Herrera 2008).

While MAPA has historically spearheaded programmes aimed at the agribusiness sector, it also supports some policies geared towards smallholders (Andrade and Miccolis 2010b). One programme led by MAPA under CONAB (National Supply Agency) is the National Food Procurement Program (PAA, or Programa de Aquisiçáo de Alimentos). Instituted by Law No. 10.696 on 2 July 2003, PAA has played an instrumental role in shifting the local supply chain for school lunches and other government food procurements by enabling local family farmers to supply their foodstuffs directly to schools (CONAB 2008a). This agency has also led to the Program for Guaranteeing Minimum Prices, which sets prices for products considered strategic for family farming and sociobiodiversity production chains, including oilseeds such as Brazil nuts and Pequi (Caryocar Brasiliensis).

While Embrapa has played a central role in generating knowledge about feedstock production, the main agency in charge of transferring this knowledge, especially to smallholders, has been EMATER, the State-level Technical Assistance and Rural Extension Agency. The guidelines for conducting technical assistance are laid out in the National Technical Assistance and Rural Extension Policy (Box 2). 


\section{Box 2. National Technical Assistance and Rural Extension Policy (ATER)}

The overall goal of the national ATER policy is to ensure free access to public technical assistance and rural extension services, in high quality and adequate quantity, which shall be targeted exclusively at family farmers, land reform settlers, as well as extractivist, riverine, indigenous, quilombola, artisanal fisherfolk and aquaculturist communities, forest peoples, rubber tappers and others defined as beneficiaries of Ministry of Agrarian Development/SAF programmes. More specifically, the policy has the following aims:

- Contribute to promoting sustainable rural development, focusing on endogenous development processes, supporting family farmers and other groups, to enable sustainable natural resource use;

- Adopt a multidisciplinary and interdisciplinary approach, encouraging the adoption of new participatory methodologies and a technological paradigm based on the principles of agroecology;

- Establish a type of management capable of democratising decision-making, contributing to building up citizenship and facilitating the process of social control of planning, monitoring, and evaluation of activities, thus enabling analysis and improvements of actions; and,

- Develop permanent and ongoing educational processes through a dialectic, humanistic and constructivistic approach, change in attitudes and procedures by stakeholders so as to further the objectives of improving the quality of living and promotion of sustainable rural development.

\subsection{Socio-biodiversity production chains}

Brazil has based a series of policies and programmes on the notion of 'sociobiodiversity products' and traditional peoples and communities. Sociobiodiversity products are defined as goods and services (end products, raw materials and benefits thereof) generated from biodiversity resources and aimed at setting up production chains in the interests of traditional communities and family farmers, and upholding and valuing their practices, knowledge and rights, so as to generate income and improve their quality of living and the environment in which they live (MDA, MMA, MDS 2009).

The main goal of the National Policy for the Sustainable Development of Traditional Peoples and Communities, or PNPCT, (instituted by Decree No. 6040, passed 7 February 2007) is to promote sustainable development among traditional communities and peoples, focusing on recognising, strengthening and ensuring their territorial, social, environmental, economic and cultural rights, respecting and valuing their identity, forms of organisation and institutions.

\subsection{Zoning instruments}

In order to provide guidelines for land allocation and rural development policies, the Federal Government commissioned two zoning studies: the National Agroecological Zoning of Sugarcane and the São Paulo Agroenvironmental Zoning of sugarcane, discussed in Part 1 as part of the sectoral policies; and, the Agroclimatic Zoning. Conducted by Embrapa and the University of Campinas, the Agroclimatic Zoning examines the suitability of nine crops (soybeans, sunflower, cottonseed, sugarcane, beans, corn, coffee, rice and cassava) according to factors such as soil, rainfall and weather conditions, as well as crop displacement due to climate change. This policy instrument is meant to guide decisions by financial institutions on issuing rural credit and farm insurance. Similarly, Ecological, Environmental, Climatic and Economic Zoning studies are drafted at the State level and also guide State rural development institutions in decisions on granting credit and issuing environmental licences and permits. 


\section{Implementation and performance}

\subsection{Labour and human rights issues in the sugarcane-ethanol industry}

The sugarcane-ethanol industry in Brazil, while touted as a clean fuel by key players from the Brazilian Government, academia and the private sector, has also given rise to human rights and labour controversies. As suggested by Andrade and Miccolis (2010a), two key events have thrust labour and human rights issues into the national and international spotlight recently: two recent conferences held in São Paulo, one championing ethanol as a clean fuel and key driver for Brazil's energy autonomy, and the other held by human rights and environmental justice groups questioning ethanol's sustainability because of its alleged impacts on local landscapes, livelihoods and human rights. Indeed, the harrowing working and living conditions, as well as cases of slave labour, found especially on the new frontiers of sugarcane cultivation, have been decried in several recent reports and studies (Sydow and Mendonça 2006; Sydow et al. 2008; Mendonça and Melo 2007, 2008a, 2008b; Suarez 2008; CPT 2008; CPT and Rede Social de Justiça e Direitos Ambientais 2008;MPS 2008; MTE 2009; Reimberg 2009; Rodrigues and Helcio 2007).

Based on an extensive literature review and analysis of claims surrounding human rights abuses, including statistics on workplace-related accidents, and reports of poor working conditions and forced labour produced by official government sources and human rights groups, Andrade and Miccolis (2010a) found that reports of forced labour and accidents have increased, while oversight and enforcement have also been bolstered. Some of the most frequent violations found through inspections include overcrowded or inadequate housing conditions, lack of personal protection equipment, lack of basic sanitation, insufficient or spoiled food, lack of drinking water, excessive workload and poor working conditions, transport and contracts.

With regard to working conditions, academic studies on ergonomics performed by Fundacentro and São Paulo State University (Unesp) show that repetitive movements and exposure to a combination of environmental risk factors in sugarcane fields can trigger accidents, cause diseases and even lead to sudden death. Moreover, these studies have drawn direct links between increased productivity targets that need to be met by sugarcane cutters according to output-based pay agreements, and increased accidents in the workplace. Indeed, the sugarcane-ethanol industry accounts for more workplace-related accidents than any other agricultural activity, as shown by Andrade and Miccolis (2010a) in Figure 4 below.

The Government and sugarcane-ethanol industry have been contesting and addressing these claims through initiatives such as the Agroenvironmental Protocol, which acknowledges companies within the sugarcaneethanol industry that are committed to adopting best practices and sustainable development, see Box 3. Recently, key stakeholders from government, industry and rural workers unions signed a 'National Commitment' aimed at rewarding and adopting best practices. A key measure in this initiative is to eliminate the middlemen, widely known as 'gatos', from the recruitment and hiring of sugarcane cutters.

\subsection{Analysis of respective interests in the sector, power differentials and avenues of influence}

The Brazilian Federal Government is investing in public infrastructure, especially transport and logistics (ethanol pipeline and multimodal systems for transporting ethanol); defining the regulatory framework; creating a safe environment for both private investors and consumers; facilitating access to credit for investment; and, fostering research and technological innovation and integration within the production chain. Meanwhile, the private sector has been investing heavily in technology and land acquisition to improve and expand ethanol and biodiesel production. In ethanol's case, the Brazilian Government's Program for Accelerated Growth (PAC) calculates that some 77 new ethanol mills 


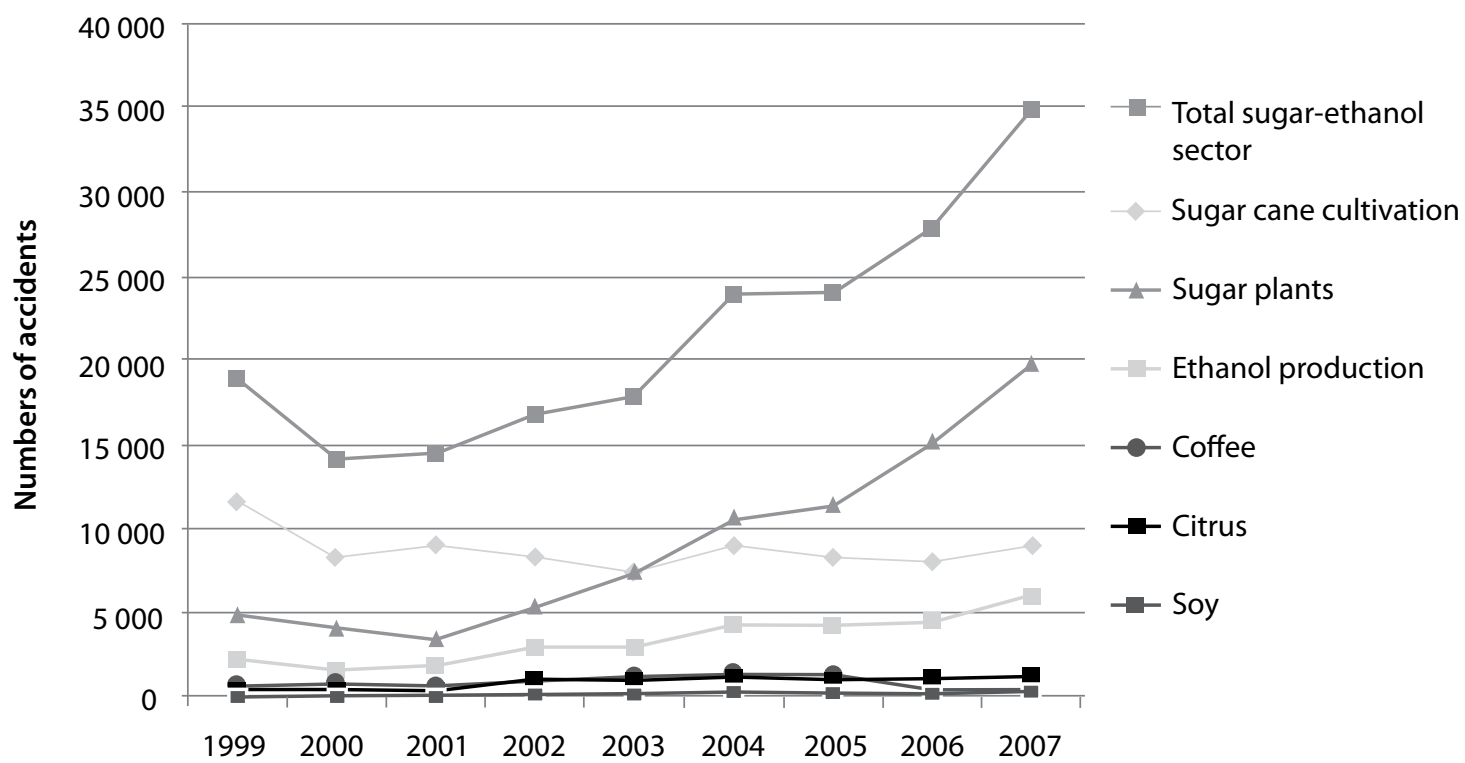

Figure 4. The agricultural sectors with the highest numbers of accidents in Brazil, 1999-2008

Source: Andrade and Miccolis 2010a, based on data from MPS 2008

\section{Box 3. National efforts to tackle forced labour}

Formerly known as the National Program for Combating Slave Labour and Irregularities in the Sugarcane-based Ethanol Sector, the National Program for Promoting Decent Work in the Sugarcane Industry is a direct response to reports of forced labour and inhumane working conditions in the sugarcane-ethanol industry. Led by the Labour and Employment Ministry with help from the Public Prosecutor's Office for Labour Affairs (MPT) and law enforcement agencies, the program was set up in 1993 with the aim of protecting the individual and social rights of workers. It has engaged in the following areas: eradicating child and slave labour, legalising labour contracts, indigenous labour issues, fighting discrimination in the workplace and preserving the health and safety of workers.

In 1995, the Brazilian Ministry of Labour and Employment (MTE) set up the National Plan for the Eradication of Forced Labour and created the Secretariat for Labour Inspection (SIT), which coordinates the Mobile Inspection Group. In 1996, former Brazilian President Fernando Henrique Cardoso launched the National Human Rights Plan, which made it mandatory for the Government to issue periodic reports on progress towards implementing human rights conventions and treaties signed by Brazil, among other measures. Since then, the MTE group has been investigating and reporting labour violations throughout the country. The results are kept in a registry of employers/farmers found perpetrating human rights abuses. As of 2008, establishments listed in the registry were barred access to public financing. That same year, the MPT created the National Program for Combating Slave Labour and Irregularities in the Sugarcane-based Ethanol Sector, which instituted a monitoring and reporting system jointly with the MTE inspection group aimed at ensuring compliance with national and international labour standards. The Labour Ministry has also stepped up efforts to tackle these claims in the field. 
will come on line by 2010, involving investments of $\mathrm{R} \$ 17.4$ billion.

In biodiesel's case, policy implementation is carried out through 13 ministries dealing with the private sector, farmers' unions and research institutes. As discussed by Abramovay and Magalhães (2007), two mechanisms draw together biodiesel producers and family farmers. First, the companies need the consent of the trade unions to sign contracts between the companies and the family farmers. Second, local councils are created to monitor contracts and targets negotiated by the companies and trade union representatives, establishing longlasting relationships between family farmers, trade unions and biodiesel producers.

\subsection{Effectiveness of environmental regulations}

One way to measure the expansion of sugarcane ethanol production is by monitoring the increase in environmental licensing for new mills. We found that in 2010, 90 new mills in the States of Goiás and Mato Grosso do Sul alone are conducting environmental licensing processes, which means an increase of $75 \%$ of total installed capacity in the region, as compared to 154 new mills under environmental licensing in the Central-South regions, which means an overall $40 \%$ increase in total installed capacity in that region.

\subsubsection{Environmental licensing in São Paulo State}

In some traditional sugarcane production regions, such as in São Paulo State and the Northeast, legal reserve areas are practically nonexistent and permanent preservation areas are quite below what is legally required (Castro 2009). So mills and distilleries already installed in these regions bear a substantial environmental liability, which stands as a key obstacle to maintaining and expanding operations and abiding by the law. In São Paulo State, the Secretariat of Environment has been negotiating with producers to strike an agreement to redress this liability. Producers have been waging legal battles based on the argument that much of the land in the region was cleared well before the current Forest Code came into effect and that biodiversity can no longer be brought back. Thus, producers have been championing an ex-situ compensation system whereby they would pay other landowners in the same watershed to conserve more of their land than legally required. It is important to note, however, that compliance with these obligations under the Forest Code is by no means homogenous in São Paulo municipalities. Recent research by the NGO S.O.S. Mata Atlântica found municipalities where less than $5 \%$ of the producing properties had legally registered reserves and other municipalities where more than $90 \%$ of properties were in compliance (Rodrigues and Ortiz 2006).

\subsubsection{The Agroenvironmental Protocol}

Another important piece of legislation at the State level is the Agriculture and Environmental Protocol for the sugarcane ethanol industry [Protocolo Agroambiental do setor sucroalcooleiro], signed by UNICA and the São Paulo State Government in June 2007. The protocol pushed out the deadline for stopping burning of sugarcane straw to 2014, while also setting up measures for protecting and recovering riverine vegetation; a technical plan for soil conservation and water resources use; measures to reduce air emissions and pesticide use; and, measures to increase mechanical harvesting in new sugarcane plantations. Similar initiatives are being implemented in the States of Minas Gerais, Goiás, Mato Grosso, Pernambuco and Alagoas.

As sugarcane producers comply with the Burning Phasing-out Law and ethanol mills comply with the São Paulo Environmental Protocol, mechanisation has some unintended effects: while ethanol distillers adopted advanced technologies to reuse waste (cogeneration, ferti-irrigation etc), planters mechanised their fields to reduce burning during harvesting and increase their productivity. Mechanisation of sugarcane harvesting had two unintended effects on manual harvesters: unemployment where mechanisation was adopted, and increased labour violations for migrant workers on farms where the labour predominantly comes from outside São Paulo State. Other unintended effects of mechanisation are felt on small and less capitalised farmers, who cannot compete against large sugarcane ethanol conglomerates, so international companies ended up buying or leasing their lands. While the Agroecological Zoning banned ethanol in the Amazon and Pantanal regions, the ZAE also 
pushed the expansion of the sugarcane ethanol sector onto other marginal and sensitive lands such as Cerrado and riverine wetlands in the Northeast (ISPN 2008).

\subsubsection{Biofuels as a threat to sensitive ecosystems and livelihoods - the case of the Cerrado and of Penedo, in Alagoas State}

A poorly addressed environmental problem stems from the expansion of sugarcane-ethanol in sensitive ecosystems. While it is true that the Amazon region is not significantly threatened, the Cerrado is widely construed as an agricultural frontier to be exploited and not as a precious biome to be preserved, although this notion is gradually changing due to the efforts of social and environmental advocacy groups. Yet it is still unclear the effect that land purchases for sugarcane production will have in displacing soy and cattle ranching, in what are known as indirect land use changes. A study conducted by ISPN (2008) reported that 27 cattle ranches migrated from the Cerrado to the Amazon region as a result of land sales for sugarcane plantations. The high impact of sugarcane on local landscapes and livelihoods has actually led some municipalities in Brazil's Mid-West to seek legal means to limit sugarcane in their territories. Even if sugarcane were to occupy only degraded pasturelands, as the Government and sugarcane-ethanol sector claim, a large part of this grazing land is located within the Cerrado ecoregion, so the native vegetation will be impeded from growing back if it is taken up by sugarcane monocrops. Additionally, according to Abramovay (2008), infrastructure projects such as the ethanol pipeline in the State of Goias strengthen the economic actors' propensity to consider the Cerrado as an area to be occupied with productive activities.

Another case study is based on doctoral research in the town of Penedo, Alagoas State, in the Northeast of Brazil (Andrade 2006). Despite the Agroecological Zoning, sugarcane expansion during the 2000s put pressure on land and transformed the landscape of sensitive ecosystems in regions outside this zoning. Some similarly unintended effects have been observed in the Northeastern region, including deforestation of riverine forests, damming of streams in wetland areas, encroachment on remnant endangered Atlantic rainforest vegetation and displacement of traditional fishing and rice farming near riverbanks and estuaries.
In Penedo, Alagoas, rice paddies and fishing nurseries were reclaimed for sugarcane ethanol after 1995 on the floodplains of the lower São Francisco River. This damaged important wetland ecosystems and river estuaries that support fish and bird breeding, and displaced local African-descendent artisanal fishing livelihoods. The region is home to more than 5000 registered fishermen and fisherwomen, whose access to fishing grounds and resources was reduced due to the sugarcane-ethanol frontier encroaching on the riverbanks and floodplains. In addition, these changes in landuse from rice to sugar-ethanol also transformed local gender-based labour. Soil and water contamination from sugarcane ethanol production (including pesticides, fertilisers, air pollution, solid and liquid residues) have also increased health problems amongst women from these communities (Andrade 2006).

\subsection{Land concentration in the hands of large ethanol corporations and displacement of smallholders}

Land concentration in the hands of fewer owners has increased over the past five years, reflecting increased FDI and new players entering the Brazilian ethanol stage. The new players are dominated by global investment funds, often headed by Brazilian investors, including BRENCO, Clean Energy Brazil, Adecoagro and Infinite Bioenergy. Key foreign investors include Sun Microsystems, AOL, Merrill Lynch, Soros and Goldman Sachs. Such projects, ranging from US\$ hundreds of millions to various US\$ billions, typically involve multiple green field investments on the new frontier with a view to becoming leading players. These companies are buying small ethanol production plants and leasing land from smallscale producers, a trend that has reduced smallholders' share in sugarcane production for ethanol from $20 \%$ to less than $15 \%$ in 2007 (Abramovay 2008).

Veiga Filho (2007) explains that ethanol-plant farm size has increased in recent years through acquisitions and leasing in the State of São Paulo areas where the mills operate. A mill sugarcane farm's average size in São Paulo grew from 8000 ha in 1970 to 12000 ha in 2001/02. Novo et al.(2010) and Nassar (2008) highlight that land prices increased more than fourfold in sugarcane regions in São Paulo State over 10 years from 1999-2008. The 
expansion of mills also boomed in these areas. According to Novo et al.(2010), 'rents in Sáo Paulo State have risen consistently over the last 13 years in 16 different sub-regions (264 municipalities) that represent the location of the new areas and also in the more traditional areas in the centre, north, and west of the state'.Fernandes et al. (2010) highlight territorial disputes between expanding sugarcane plantations and agrarian reform settlements, with displacement of small farmers, as well as biodiesel production projects developed by the Landless Workers Movement (MST) and the Western São Paulo Federation of Settlement and Family Farmer Associations (FAAFOP).

\subsection{Effectiveness of energy and agroenergy policies}

According to Macedo (2007a), among other scholars, ethanol has achieved substantial results since it was first included in the national energy mix in 1975, namely: a) production and demand widely exceeded initial expectations at the outset of Pro-Alcool; b) improvements in technology and management made this renewable fuel less dependent on policies to offset the more competitive fossil fuel prices (i.e. direct and indirect subsidies); and, c) the physical characteristics of ethanol enabled greenhouse gas emission reductions.

Over the past 40 years, the sugarcane-ethanol industry has expanded its operations from the northeastern States of Alagoas and Pernambuco and the southeastern State of São Paulo towards the rest of the country, especially the Mid-western and so-called South-Central region. Launched in 1975, the Pro-Alcool Program fueled the expansion of the sugarcane frontier and boom in ethanol production. Since the 1980s, Brazil has passed India and Cuba as the largest sugarcane producer in the world. Regulation was important for the first wave of ethanol expansion, although the biggest boom occurred during the period marked by deregulation after 1992, when the main drivers for sugarcane-ethanol expansion in Brazil were market opportunities and the advent of flexfuel cars in 2003, as well as State and national policies that promoted ethanol production and commercialisation (Fischer et al. 2008).
As a result of these policies and programmes, especially the success of the ethanol policies, Brazilian biofuels have been thrust into the international spotlight. In 2007, the then US President George Bush visited Brazil to sign a bilateral cooperation agreement on ethanol with President Lula da Silva. In 2009, President Luiz Inácio Lula da Silva and former US President Bill Clinton spoke about the sustainability of ethanol in Brazil and the US at the Ethanol Summit (2009) in São Paulo. Ethanol in Brazil evidently held many socioeconomic and environmental advantages over the corn programme in the US, especially in terms of climate change mitigation strategies, lack of direct subsidies and its job creation potential.

A quick look at corn-ethanol in the US following the 2005 Energy Act shows it has been a fiasco. First, corn-based ethanol did not significantly reduce US oil imports; second, adding more ethanol to gas tanks further complicated the motor-fuel supply chain, leading to further price hikes at the pump; and, lastly, it may take more energy to produce a gallon of corn ethanol than the energy the fuel actually contains. Indeed, the Energy Act is the latest instalment of the ethanol subsidy, a handout that has cost American taxpayers billions of dollars during the last three decades. Between 1995 and 2003, federal subsidies for corn totalled $\$ 37.3$ billion, which is more than twice the amount spent on wheat subsidies, three times the amount spent on soybeans, and 70 times the amount spent on tobacco.

On the other hand, the Brazilian biofuels programme also gave rise to many controversies regarding human rights, labour health risks and environmental impacts, especially water and air pollution, as discussed in Section 5.2 above (Andrade and Miccolis 2010a).In a very recent episode, due to a long drought and following heavy rainfall, the sugarcane harvest experienced a drop, and sugarcane based ethanol has been falling short at the pumping stations, and Brazil had to import corn-based ethanol to supply its internal market and increasing demands of mixed gasoline. 


\subsection{Effectiveness of trade and investment policy}

A wide diversity of investment sources is pushing the ethanol sector. Wilkinson and Herrera (2008) describe key players in the process as:

1. Leading players such as Cosan which bought up ESSO's network of filling stations; and Crystalev which, in addition to developing a bioplastics operation with Dow Chemical, is developing biodiesel from sugarcane in collaboration with Amyris.

2. Global traders: Ex: Dreyfuss, Tereos, Cargill, Bunge, Archer Daniels Midland and Noble.

3. Brazilian transnationals Odebrecht, Petrobrás, Vale and Votorantim are investing heavily in cutting-edge research and innovation related to sugarcane and biodiesel. Votorantin is investing in firms such as Alellyx and Canavialis through its Biotechnology Investment Fund.

Although the majority of mills are individually owned, the leading firms - Cosan, Crystalev and Nova America - all have numerous plants and are involved in consolidation. Foreign investment has been traditionally low with global players preferring minority stakes. According to Wilkinson and Herrera (2008: 5), 'this situation is rapidly changing, with acquisitions and particularly greenfield investments prevailing'. Some 40 firms control $50 \%$ of the sector's production and this number is expected to drop to six to eight companies in 10 years, with projections that foreign companies will take up $50 \%$ of market share, a sharp rise from the current $25 \%$.

Wilkinson and Herrera (2008) show that foreign capital can be divided between consortiums and funds with no operational track records in the sector, and those already up and running. With regard to investment and credit in the biodiesel sector, in 2005 the Government forecast growth in government and private sector lines of credit, without setting targets. By 2009, the Federal Government financed up to $90 \%$ of overall investments in the sector.
Meanwhile, biodiesel investments are evolving, mostly with national capital, PNA (National Agroenergy Plan) and PNPB policies and specific lines of financing (BNDES; FINEP, the National Fund for Studies and Research; CNPq, the National Research Council; State research foundations; private institutions), which are also funding biodiesel $\mathrm{R} \& \mathrm{D}$ through the Brazilian Network of Biodiesel Technology (RBTB).

\subsection{Biodiesel subject to oil market}

The basic principles laid out in the PNA and PNPB (CEIB 2006) give government agencies the power to develop standards for biodiesel consumption, production and distribution. These biodiesel standards are integrated, both physically and legally, with the diesel and gasoline system, which means that the Government, through its regulatory agency ANP and Petrobrás, is subject to the wider oil market forces. Ultimately, this undermines some of the PNA and PNPB goals, such as the requirement to source a certain percentage of feedstock from smallholders, as prescribed under the Social Fuel Stamp (IPEA 2010).

\subsection{Effectiveness of the PNPB and Social Fuel Stamp}

The Social Fuel Stamp has so far generally not met targets for jatropha and castor oil bean-based family farming systems in poor regions. Originally designed to include family farmers from the poorest regions (North and Northeast) (Siniscalchi 2010) in the biodiesel production chain, this certification system focused initially on castor beans and jatropha as promising feedstocks that could grow on family farms under harsh conditions. However, according to IPEA (2010), instead of reaching out to smallholders as first intended, the Stamp gave companies credentials that in turn provided access to tax incentives for industries and greater market access. In 2009, 92\% of biodiesel industries held the Stamp, according to Repórter Brasil (2009), which was made possible by purchasing soybeans from farmers in the Mid-west, technically classified as family farmers who do not need technical assistance 
as they have been planting soybeans for the past 15 years. In addition to the IPEA study, a series of recent on-the-ground studies have pointed to the PNPB's lack of success due to various factors, including: structural constraints such as lack of highquality technical assistance; lack of land tenure; and, breaches in contracts with castor bean producers (IPEA 2010; Wilkinson and Herrera 2010; Finco and Doppler 2010; Obermaier et al. 2010). Castor and Jatropha crop failure has also hindered a better functioning of the stamp and supply chain, which is further aggravated by the high opportunity cost of castor bean oil on the international market for other uses. Additional obstacles have been lack of affinity and training among smallholders unused to cultivating such crops, low average income generation per hectare in the Northeast and North regions, and low value addition by family farmers who generally only supply unprocessed seeds. (IPEA 2010; Wilkinson and Herrera 2010; Obermaier et al. in press and 2010; Repórter Brasil 2009). So while some strides have been made to include family farmers in the biodiesel production chain and increase their market access (Obermeier et al. 2010), these gains have been largely fueled by Petrobrás' role in purchasing feedstock and financing new processing plants.

Additionally, according to a recent case study conducted in two regions of Tocantins State among smallholders, both jatropha and castor bean production have been implicated in deforestation by replacing land previously used for food production (cassava, rice and maize), and thus aggravating food insecurity among farmers who already face food shortages on a regular basis (Finco and Doppler 2010). There is wide-reaching consensus among scholars that biodiesel production is bound to continue relying heavily on soybeans. According to Wilkinson and Herrera (2010), among others, this scenario is likely to continue having significant negative impacts on land concentration, deforestation and $\mathrm{CO}_{2}$ emissions due to indirect land use changes stemming from the displacement of large cattle herds.

Meanwhile, the Government has been championing oil palm as the great new hope for family farmingbased feedstock production in the Amazon, due to the vast stretches of suitable lands in the region, phenomenal yields and other cropping characteristics that make oil palm amenable to smallholder production (Andrade and Miccolis 2010b). While the economic potential for growing oil palm in the Amazon is undeniable, several recent studies have questioned the extent to which oil palm can be socially and environmentally sustainable given current cropping systems and integration agreements. (Repórter Brasil 2009; Butler and Laurance 2009; Andrade and Miccolis 2010b; Fitzherbert et al. 2008 Camargo 2009). While industry-led initiatives such as the Roundtable on Sustainable Palm Oil (RSPO) have established guidelines and best practices, monitoring and enforcing these practices on the ground is a huge challenge in light of the weak governance structures in most of the Brazilian Amazon (Andrade and Miccolis 2010b; RSPO 2008). 


\section{Conclusions}

The Brazilian biofuels sector is likely to keep growing by leaps and bounds as investments keep rising in lockstep with domestic and international demand. Beyond the country's long trajectory of massive investments in technology, production and distribution infrastructure dating back to the 1970s, policies and measures over the last decade have provided financial incentives, bolstered exports and spurred foreign direct investment, especially in the ethanol sector. Moreover, Brazil's vast agricultural frontier, marginal lands and highly favourable climatic conditions undoubtedly place the country in a privileged position to expand biofuels production.

Our analysis of the key players and policies within and outside the biofuels sector points to a torrent of forces contributing to the expansion of both ethanol and biodiesel, but it also points to significant obstacles. As biofuels have become a mainstay of the country's renewable energy, climate change and rural development policies, concerns surrounding environmental, human rights and land concentration issues have led to stricter zoning laws and increased enforcement of labour and environmental regulations in some regions, as well as new land acquisition restrictions nationwide. While compliance with environmental and labour standards has clearly improved in São Paulo State, reports of human rights abuses, increasing land concentration and destruction of sensitive habitats have been raising eyebrows elsewhere in the vast new frontier of sugarcane and biodiesel. Although the Amazon and Pantanal eco-regions have been ruled out of ethanol production and the Government has taken substantial measures aimed at social inclusion and benefiting family farmers producing biodiesel, large swaths of Cerrado vegetation are being converted to sugarcane and soybean production in central Brazil, where environmental regulations are deemed more permissive (ISPN 2008; Abramovay 2008).

On the one hand, biofuels in Brazil are being touted by the Government and key industry players as a shining example of 'clean' and renewable energy that reduces greenhouse gas emissions, substitutes fossil fuels, creates jobs and spurs rural development without undermining food production. On the other hand, recent on-the-ground studies have shown that despite sizeable government efforts to promote the social inclusion of family farmers in biodiesel production, biodiesel expansion might be achieved at the expense of deforestation, rural livelihoods and food security (Wilkinson and Herrera 2010; Finco and Doppler 2010), while also falling short of expectations with regard to income generation and job creation.

Although biodiesel policies have clearly tried to learn from the shortcomings of the highly deregulated ethanol market by rendering biodiesel more propoor, the jury is still out as to the success of these policies in improving rural livelihoods and protecting ecosystems. The National Biodiesel Program (PNPB), which focused initially on castor beans and later on jatropha as promising crops for smallholders in the semi-arid Northeast, has since shifted attention to other oilseeds such as oil palm, which is currently being touted as the promising new crop for bioenergy in the Amazon region. Although the number of family farmers benefited by the PNPB has risen sharply, from around 50000 to close to 100000 families in 2010 (ANP 2010), smallholders still only produce around $20 \%$ of all raw materials for biodiesel and their continuing access to the biodiesel market is likely to rely more on the perpetuation of these public policies than on market forces (Wilkinson and Herrera 2010).

While the Government has set up numerous mechanisms to address the concerns surrounding the impacts of expanding sugarcane, some measures, such as the Agroecological and the Agroenvironmental Zoning, are restricted to certain regions and difficult to enforce on Brazil's vast agricultural frontiers. As policies to reregulate ethanol are likely to continue driving the expansion of this 'clean' fuel, wider agricultural, agroenergy and FDI policies will undoubtedly continue to spur biodiesel feedstock production among corporate soybean farmers and smallholders. 
As this paper is going to press, recent market and policy forces are bound to significantly alter the landscape for expanding biofuels in Brazil. First, discussions are underway in the National Congress to loosen environmental restrictions on land use under the new Forest Code, especially among smallholders; this will tend to increase pressure on environmentally sensitive areas such as riverbanks and hillsides. Meanwhile, the rising global demand for food and fuel, especially in emerging economies such as China, is leading to a land grab in Brazil. This in its turn will also tend to increase pressure on sensitive ecosystems and rural livelihoods despite government efforts to the contrary.

So while the Brazilian Federal and several State governments have been taking considerable steps to include family farmers in the biofuels production chain, questions still remain as to the social, economic, and environmental sustainability of key feedstock. Although one might argue that policies targeting smallholders have had some degree of success due to the increased number of families involved in biodiesel programmes, overall these policies still seem to face an uphill battle due to structural constraints and inequalities in Brazil's poorest regions.

Furthermore, these policies underpinned by the concept of 'social inclusion', which have been the flagship of Brazil's approach to biodiesel production, stand in stark contrast to wider rural development policies, including ethanol and agronergy policies, which have tended to favour the agribusiness and corporate farming model. Ultimately, the sustainability of Brazil's biofuels policies seems to hinge on strengthening governance mechanisms and wider rural development policies such as technical assistance, land tenure and rural credit. The sustainable expansion of biofuels, in terms of social and environmental impacts, depends on enabling the effective implementation of current policies, which are generally laudable on paper but difficult to enforce in practice. At the same time new policies are needed to bridge the huge gap that still separates small-scale family farmers from large-scale corporate farmers in their access to government programmes and in sharing the benefits from biofuels production. 
Abramovay, R. 2008 A political-cultural approach to the biofuels market in Brazil. Universidade de São Paulo. http://www.abramovay.pro.br/ artigos_jornal/2008/Abramovay_Ethanol_ biodiesel_Brazial_political_cultural_approach.pdf (July 2010).

Abramovay, R. and Magalháes, R. 2007 O acesso dos agricultores familiares aos mercados de biodiesel. Parcerias entre grandes empresas e movimentos sociais. Texto para discussão 6. São Paulo.

Amaral, W.A.N., Marinho, J.P., Tarasantchi, R., Beber, A. and Eduardo, G. 2008 Environmental sustainability of sugarcane ethanol in Brazil. In: Zuurbier, P. and van de Vooren, J. (eds) Sugarcane ethanol contributions to climate change mitigation and the environment. Wageningen Academic Publishers.

Andrade, R. and Miccolis, A. 2010b Biodiesel in the Amazon. Working paper 113. CIFOR/ICRAF, Nairobi.

Andrade, R.M.T. 2006 The third edge of the lower São Francisco River: culture, power and nature in Northeast Brazil. Doctoral dissertation. University of California at Berkeley, California, USA.

Andrade, R.M.T. and Miccolis, A. 2010a The expansion of sugarcane-ethanol in Brazil and controversies surrounding human rights: contesting the green fuel. Controversies in Science and Technology 3. From Evolution to Energy. http://www.liebertpub. com/products/toc.aspx?pid=374 (10 May 2011).

Arco Verde Terra Legal 2009. www.mda.gov.br/ arcoverde/ (6 May 2009).

BCB (Banco Central do Brasil) 2009 A economica global e as perspectivas para o agronegocio no Brazil. [10 December 2009] http://www.bcb.gov. br/pec/appron/Apres/HM_FAEG_06072009_ fim.pdf.

Beltrão, S. 2009 A indústria do biodiesel no Brasil. Brasília.

BiodieselBR (no date) Legislação edecretos sobre biodiesel. http://www.biodieselbr.com/ biodiesel/legislacao/legislacao-biodiesel.htm (7 December 2009).

BNDES (Brazilian National Development Bank) Centro de Gestão e Estudos Estratégicos
2008 Bioetanol de cana de açúcar: energia para um desenvolvimento sustentavel. http://www. bioetanoldecana.org (6 March 2009).

Brancalion, P.H.S. and Rodrigues, R.R. 2010 Agricultural land reduction due to the compliance with the current Forest Code: a study case of sugarcane production in the State of São Paulo. Biota Neotropica 10(4). http://www.biotaneotropica. org.br/v10n4/en/abstract?article+bn01010042010 (20 January 2011).

Brandt, R. 2008 Trabalho escravo resiste e Brasil liberta 4418 pessoas em um ano. O Estado de São Paulo, 22 December.

Brannstrom, C., Rausch, L., Brown, C., Andrade, R.M.T and Miccolis, A. 2011 Compliance and market exclusion in Brazilian agriculture: analysis and implications for 'soft' governance. Land Use Policy (accepted).

Butler, R.A. and Laurance, W.F. 2009 Is oil palm the next emerging threat to the Amazon? Tropical Conservation Science 2(1):1-10.

Camargo, R. 2009 Expansão do Plantio do Dendê na Amazônia Gera Polêmica: Congresso em Foco, http://congressoemfoco.ig.com.br/Ultimas. aspx?id=26269 (23 May 2009).

Castro, L.L.B. 2009 Alcances e Vulnerabilidades da Avaliação de Impactos Ambientais no Setor Sucroenergético Paulista. Masters Thesis, Universidade Federal do ABC. Santo Andre.

CEIB (Comissão Executiva Interministerial) 2006 Plano Nacional de Produção e Uso de Biodiesel - PNPB. http://www.biodiesel.gov.br. (January 2010).

Coelho, S.T. 2008 Vocação Inegável. Revista Brasileira de Bioenergia2(4) November:5.

CONAB 2008a Programa de Aquisição de Alimentos. www.conab.gov.br/conabweb/agriculturaFamiliar/ paa_o_que_e.html. (12 May 2009).

CONAB 2008b Acompanhamento da safra brasileira de cana de açúcar. Segundo levantamento. www. conab.gov.br/conabweb/download/safra/cana.pdf. (18 May 2009).

COPPEAD, IBP 2007 Planejamento Estratégico e Logístico para o Programa Nacional de Biodiesel: Relatório Final. Rio de Janeiro: Universidade Federal do Rio de Janeiro. 
CPT 2008 Etanol e trabalho escravo: aonde o governo Brasileiro quer chegar? CPT http://storage. paxchristi.net/PUBLIC/2008-0840-po-am-HS.pdf (10 May 2009).

CPT, Rede Social de Justiça e Direitos Ambientais 2008 Os impactos da produçáo de Cana No Cerrado e Amazônia. São Paulo and Recife: Comissão Pastoral da Terra e Rede Social de Justiça e Direitos Humanos. http://www.cptnac.com.br (28 September 2008).

EPE (Energy Research Company) 2009 Plano Decenal de Energia 2009-2019. Rio de Janeiro.

Ethanol Summit 2009 http://www.ethanolsummit.com. br/ (December 2009).

Fernandes, B. M., Welch, C.A. and Gonçalves, E.C. 2010 Agrofuel policies in Brazil: paradigmatic and territorial disputes. Journal of Peasant Studies 37(4): 793-819.

Finco, M.V.A. and Doppler, W. 2010 Bioenergy and sustainable development: the dilemma of food security and climate change in the Brazilian savannah. Energy for sustainable development 14(2010): 194-199.

Fitzherbert, E.B., Struebig, M.J., Morel, A., Danielsen, F., Bruhl, C.A., Donald, P.F. and Phalan, B. 2008 How will oil palm expansion affect biodiversity? Review in Trends in Ecology and Evolution 23(10). Elsevier.

Hall, J., Matos, S., Severino, L. and Beltrão, N. 2009 Brazilian biofuels and social exclusion: established and concentrated ethanol versus emerging and dispersed biodiesel. Journal of Clean Production. doi:10.1016/j.jclepro.2009.01.003.

Holanda, A. 2004 Biodiesel e Inclusão Social. Brasilia:. Câmara dos Deputados. Brasília. http://www. ambiente.sp.gov.br/legislacao/estadual/resolucoes (15 May 2009).

IBGE 2006 Censo Agropecuário, Brasil.http:// www.ibge.gov.br/home/estatistica/economia/ agropecuaria/censoagro/2006/agropecuario.pdf (June 2007).

INCRA (National Colonization and Agrarian Reform Institute) 2009 Atlas Fundiário do Instituto Nacional de Colonização e Reforma Agrária. Brasilia. http://www.incra.gov.br/portal/ index.php?option $=$ com_docman $\&$ task $=$ doc_ details\&gid=457\&Itemid=143 (June 2010).

IPEA (Applied Economic Research Institute) 2010 Biocombustiveis no Brasil: etanol e biodiesel. Serie Eixos do Desenvolvimento Brasileiro. Comunicados IPEA N 53. Brasilia. http://
agencia.ipea.gov.br/images/stories/PDFs/100526 comunicadodoipea_53.pdf (November 2010).

ISPN (Institute for Society, Population and Nature) 2008 Cana-de-açúcar avança em áreas prioritárias para a conservaçấo e uso sustentável do Cerrado http://www.observatoriodoagronegocio.com. br/page41/files/LevantamentoCanaNilo.pdf. (June 2009).

Jornal da Cana 2006 Estudo pretende incentivar a produção de pequenas destilarias. http://www. jornalcana.com.br/pdf/152/\%5Cpolitseto.pdf (20 July 2008).

Leão, L. 2008 Usinas de cana de Pernambuco autuadas por crime ambiental. Globo. http://www. reporterbrasil.org.br/pacto/clipping/view/547 (1 July 2008).

Luna, D. 2008 Cane surpasses power dams in Brazil energy complex, Environmental News Network. http://www.enn.com/top_stories/article/36015 (August 2011).

Macedo, I.de C. 2007a Sugar cane's energy: twelve studies on Brazilian sugar cane agribusiness and its sustainability. National Union of Sugarcane and Ethanol Industry (UNICA), São Paulo.

Macedo, I.de C. 2007b A energia da cana-de-açúcar. Paper presented at Sugar-based ethanol: energy for sustainable development] http://unica.com.br/ multimedia/ (accessed 14 May 2009).

MAPA (Ministry of Agriculture, Livestock and Food Supply) 2006 Plano Nacional de Agroenergia 2006-2011.Embrapa Informacão Tecnológica, Brasilia.

MAPA (Ministry of Agriculture, Livestock and Food Supply) 2008 Zoneamento agroecologico da cana de açucar no Brasil. Brasília.

MAPA (Ministry of Agriculture, Livestock and Food Supply) 2009 Programa de Biodiesel garante diesel mais limpo no Brasi. http:// www.portaldoagronegocio.com.br/conteudo. php?a=impresSão\&id=30615 (2 July 2009).

MAPA, MCT, MME, MDIC (Ministry of Agriculture, Livestock and Food Supply; Ministry of Science and Technology; Ministry of Mines and Energy; Ministry of Development, Industry and Trade) 2006 Diretrizes de política de agroenergia. Brasília. http://www.biodiesel.gov.br/docs/diretrizes03.pdf (August 2011).

MDA (Ministry for Agrarian Development) 2009a Biodiesel Combustível Social. www.mda.gov (12 July 2009). 
MDA (Ministry of Agrarian Development) 2010 PLANO SAFRA 2010/2011. Brasília.

MDA (Ministry of Agrarian Development) 2009b Portal do Pronaf: Biodiesel: http://www.mda.gov. br/saf/ (15 July 2009).

MDA, MMA, MDS (Ministry of Agrarian Development; Ministry of the Environment; Ministry of Social Development) 2009 Plano Nacional de Promoção das Cadeias de Produtos da Sociobiodiversidade.

MDA/SAF (Ministry of Agrarian Development/ Secretaria de Agricultura Familiar) 2007 Política Nacional de Assistência Técnica e Extensão Rural. www.mda.gov.br/portal/saf/. (3 May 2009).

MDIC (Ministry of Development, Industry and Trade) 2010 Alcool combustivel http://www.mdic.gov. $\mathrm{br} /$ sitio/interna/interna.php?area $=2 \&$ menu=999 (2 January 2011).

Mendonça, M.L. and Melo, M. 2007 Agroenergia: Mitos e Impactos, Rede Social de Justica e Direitos Humanos. Indústria da Cana: Rede Social de Justiça e Direitos Humanos. http://www.social.org. br (5 April 2009).

Mendonça, M.L. and Melo, M. 2008a Monocultura da Cana-Açúcar Cresce, e Exploração dos Trabalhadores Aumenta. http://www3.brasildefato. com.br (26 April 2008).

Mendonça, M.L. and Melo, M. 2008b A Expansão Canavieira no Brasil de Fato. http://www3. brasildefato.com.br (1 January 2009).

Miccolis, A. 2008 Cadeias Produtivas da Sociobiodiversidade: gargalos nos marcos regulatórios. FAO, Ministry of the Environment (unpublished technical report).

Moreira, J. R., Goldemberg, J. 1999 The alcohol program. Energy Policy27(4): 229-245.

MPS (Ministry of Social Security) 2008 Estatística de Acidentes. http://www.previdenciasocial.gov.br (13 April 2009).

MTE (Ministry of Labour) 2009 Lista Suja do Trabalho Escravo: Repórter Brasil/ http://www. reporterbrasil.com.br/listasuja/ (10 May 2009).

NAE (Núcleo de Assuntos Estratégicos da Presidência da República) 2004 Caderno 2, Biocombustíveis. Brasília.

Nassar, A.M., 2009 Brazil as an agricultural and agroenergy superpower. In: Brainard, L. and Martinez-Diaz, L. (eds), Brazil as an economic superpower? understanding Brazil's changing role in the global economy, 55-80. Brookings Institution Press, Washington, DC.

Novo, André, Jansen, K., Slingerland, M. and Giller, K. 2010 Biofuel, dairy production and beef in Brazil: competing claims on land use in São Paulo state. Journal of Peasant Studies 37(4): 769-792.

Obermaier, M., Herrera, S. and Lébre la Rovere, E. 2010 Análise de problemas estruturais da inclusão da agricultura familiar na cadeia produtiva de biodiesel. In: Anais do IV Congresso Brasileiro de Mamona e I Simpósio Internacional de Oleaginosas Energéticas, João Pessoa, PB. Inclusão Social e Energia 326-331.

Obermaier, M., Oberling, D.F. and La Rovere, E.L. (in press) A expansão dos biocombustíveis e potenciais impactos sobre a segurança alimentar: evidências recentes do Brasil. In: Leite, S.P. et al.(eds), Segurança alimentar e segurança energética. Chemical Producers and Distributors Association, Rio de Janeiro.

Reimberg, M. 2009 Denúncias sobre trabalho escravo atingem recorde em 2008. Repórter Brasil, 1 May. http://www.reporterbrasil.org.br/exibe. php?id=1567 (November 2009).

Repórter Brasil 2008a O Brasil dos agrocombustíveis: palmaceas, algodão, milho e pinhão-manso. Brazil. http://www.agrocombustiveis.org.br (10 May 2009).

Repórter Brasil 2008b O Brasil dos agrocombustíveis: soja e mamona.Brazil. http://www.reporterbrasil. com.br/listasuja/ (10 May 2009).

Repórter Brasil 2009 O Brasil dos agrocombustíveis: cana de acucar.Brazil. http://www.reporterbrasil. org.br (12 May 2009).

Rodrigues, A. and Hélcio, N. 2007 A morte por trás do etanol: Revista Istoé Online 1952, 28 March.

Rodrigues, D. and Ortiz, L. 2006 Em direção à sustentabilidade da produçáo de etanol de cana de açúcar no Brasil. http://www.vitaecivilis. org.br/anexos/ethanol_sustainability.pdf (19 January 2010).

Roundtable on Sustainable Palm Oil (RSPO) 2008 http://www.rspo.org (20 July 2009).

Rousseff, D. 2004 Programa Nacional de Produção e Uso de Biodiesel: http://www.biodiesel.gov.br/ (5 February 2009).

Santos, A.M. 2008 Análise do Potencial do Biodiesel de Dendê para a Geração Elétrica em Sistemas Isolados da Amazônia. Mestrado, Universidade Federal do Rio de Janeiro, 2008. 
Sassine, V. 2010 Mudança no Código Florestal pode resultar no desmatamento de 80 milhóes de hectares. Correio Braziliense. (21 June 2010).

Schlesinger, S. 2008 Soja: o grão que segue crescendo. Grupo de Trabalho sobre Desenvolvimento e Meio Ambiente nas Américas. July 2008.

Siniscalchi, C.R. 2010 Análise da viabilidade da inserção da agricultura familiar do semiárido no programa nacional de produçáo e uso de biodiesel: o caso do Ceará. Dissertação de mestrado. Universidade Federal do Rio de Janeiro, Rio de Janeiro, Brazil.

SMA-SAA 2008 Resolucao conjunta SMA-SAA No 4 de 18 de Setembro de 2008. Dispóe sobre o Zoneamento Agroambiental para o setor sucroalcooleiro no Estado de São Paulo. São Paulo. http://www.ambiente.sp.gov.br/ contAmbientalLegislacaoAmbiental.php (June 2009).

SMA 2008 Zoneamento agroambiental para o setor sucroalcooleiro. http://www.ambiente.sp.gov.br/ etanolverde/zoneamentoAgroambiental.php\# (June 2009).

Smeets, E., Junginger, M., Faaij, A., Walter, A. and Dolzan P. 2006 Sustainability of Brazilian bioethanol. Universidade Estadual de Campinas. São Paulo, Brazil.

Souza, J. 2009 Dendê: potencial para produção de energia renovável. Disponível em www.ceplac.gov. br/radar/Artigos/artigo9.htm (15 July 2009).

Suarez, S.M. 2008 Agrofuels in Brazil: fact-finding mission report on the impacts peoples and peasants in Brazil,executive summary. Food-First Information and Action Network, Heidelberg, Germany.
Sydow, E., Mendonça, M.L. and Melo, M. 2008

Direitos humanos e cana de açúcar. Rede social de justiça e direitos humanos. http://www.social.org. br/artigos/artigo033.htm (May 2009).

Sydow, E. and Mendonça, M.L. 2006 Direitos humanos no Brasil: rede social de justiça e direitos humanos. http://www.social.org.br (5 May 2009).

Veiga Filho, A.A. 2007 Novo ciclo do Proálcool: problemas derivados do aumento da produçáo do etanol. Com Ciência 86. http://www.comciencia. $\mathrm{br} /$ comciencia $/$ section $=8 \&$ edicao $=23 \& i d=257$. 17 April 2007.

Villela, A.A. 2009 O Dendê como Alternativa Energética Sustentável em Áreas Degradadas da Amazônia. Dissertação de mestrado. COPPE/UFRJ.

Walter, A., Dolzan, P., Quilodrán, O., Garcia, J., da Silva, C., Piacente, F. and Segerstedt, A. 2008. A sustainability analysis of the Brazilian ethanol. Universidade Estadual de Campinas.

Wilkinson, J. and Herrera, S. 2008 Subsídios para a discussão dos agrocombustíveis no Brasil. Agrocombustíveis e a Agricultura Familiar e Camponesa, 2008, FASE/Rede Brasileira pela Integração dos Povos.

Wilkinson, J. and Herrera, S. 2010 Biofuels in Brazil: debates and impacts. Journal of Peasant Studies 37(4): 749-768.

World Bank 2010 Doing business, paying taxes in Brazil. http://www.doingbusiness. org/exploretopics/payingtaxes/details. aspx?economyid=28 (December 2010). 


This paper maps out and analyses the wide range of policies and players that have shaped the phenomenal rise of biofuels in Brazil, drawing comparisons between the ethanol and biodiesel industries. The sugarcane-ethanol sector's expansion has been characterised by distinct waves of regulation and deregulation, heavy private investment and public financing for infrastructure, research and development. Close links with energy and climate change-related policies, the dualfuel car revolution, liberal foreign direct investment policies and fiscal and financial incentives have also played important roles.

Questions are being raised about human rights and environmental justice due to poor working conditions, land concentration and displacement of smallholders as well as environmental impacts, especially in South-Central and Northeastern Brazil. The sugarcane-ethanol industry has sought to address these claims through voluntary governance and certification mechanisms. The Brazilian Government has also taken decisive action to forbid sugarcane expansion into sensitive ecosystems.

Recent biodiesel feedstock policies aimed at smallholders have delivered substantial savings (US\$1 billion/year) by substituting diesel imports, and made progress towards 'social inclusion'. But these programs have fallen short of targets, as the prevailing feedstock is still soybeans followed by beef tallow, with production and processing still concentrated in the hands of large-scale soybean farmers and cattle ranchers. Despite robust and well-intended environmental, rural development and fiscal policies to support smallholders, some policies are extremely difficult to enforce given structural constraints faced by smallholders and the lack of adequate governance mechanisms. policies and practices that affect forests in developing countries. CIFOR is one of 15 centres within the Consultative Group on International Agricultural Research (CGIAR). CIFOR's headquarters are in Bogor, Indonesia. It also has offices in Asia, Africa and South America. 